\title{
Investigation of the global methane budget over 1980-2017 using GFDL-AM4.1
}

\author{
Jian He ${ }^{1,2}$, Vaishali Naik ${ }^{2}$, Larry W. Horowitz ${ }^{2}$, Ed Dlugokencky $^{3}$, and Kirk Thoning ${ }^{3}$ \\ ${ }^{1}$ Program in Atmospheric and Oceanic Sciences, Princeton University, Princeton, New Jersey, USA \\ ${ }^{2}$ NOAA Geophysical Fluid Dynamics Laboratory, Princeton, New Jersey, USA \\ ${ }^{3}$ NOAA Earth System Research Laboratory, Boulder, Colorado, USA
}

Correspondence: Jian He (jian.he@ noaa.gov)

Received: 3 June 2019 - Discussion started: 12 July 2019

Revised: 18 October 2019 - Accepted: 16 December 2019 - Published: 23 January 2020

\begin{abstract}
Changes in atmospheric methane abundance have implications for both chemistry and climate as methane is both a strong greenhouse gas and an important precursor for tropospheric ozone. A better understanding of the drivers of trends and variability in methane abundance over the recent past is therefore critical for building confidence in projections of future methane levels. In this work, the representation of methane in the atmospheric chemistry model AM4.1 is improved by optimizing total methane emissions (to an annual mean of $580 \pm 34 \mathrm{Tg} \mathrm{yr}^{-1}$ ) to match surface observations over 1980-2017. The simulations with optimized global emissions are in general able to capture the observed trend, variability, seasonal cycle, and latitudinal gradient of methane. Simulations with different emission adjustments suggest that increases in methane emissions (mainly from agriculture, energy, and waste sectors) balanced by increases in methane sinks (mainly due to increases in $\mathrm{OH}$ levels) lead to methane stabilization (with an imbalance of $5 \mathrm{Tg} \mathrm{yr}^{-1}$ ) during 1999-2006 and that increases in methane emissions (mainly from agriculture, energy, and waste sectors) combined with little change in sinks (despite small decreases in OH levels) during 2007-2012 lead to renewed growth in methane (with an imbalance of $14 \mathrm{Tg} \mathrm{yr}^{-1}$ for 2007-2017). Compared to 1999-2006, both methane emissions and sinks are greater (by 31 and $22 \mathrm{Tg} \mathrm{yr}^{-1}$, respectively) during 2007-2017. Our tagged tracer analysis indicates that anthropogenic sources (such as agriculture, energy, and waste sectors) are more likely major contributors to the renewed growth in methane after 2006. A sharp increase in wetland emissions (a likely scenario) with a concomitant sharp decrease in anthropogenic emissions (a less likely
\end{abstract}

scenario), would be required starting in 2006 to drive the methane growth by wetland tracer. Simulations with varying $\mathrm{OH}$ levels indicate that a $1 \%$ change in $\mathrm{OH}$ levels could lead to an annual mean difference of $\sim 4 \mathrm{Tg} \mathrm{yr}^{-1}$ in the optimized emissions and a 0.08-year difference in the estimated tropospheric methane lifetime. Continued increases in methane emissions along with decreases in tropospheric $\mathrm{OH}$ concentrations during 2008-2015 prolong methane's lifetime and therefore amplify the response of methane concentrations to emission changes. Uncertainties still exist in the partitioning of emissions among individual sources and regions.

\section{Introduction}

Atmospheric methane $\left(\mathrm{CH}_{4}\right)$ is the second most important anthropogenic greenhouse gas with a global warming potential 28-34 times that of carbon dioxide $\left(\mathrm{CO}_{2}\right)$ over a 100 year time horizon (Myhre et al., 2013). Methane is also a precursor for tropospheric ozone $\left(\mathrm{O}_{3}\right)$ - both an air pollutant and greenhouse gas - influencing ozone background levels (Fiore et al., 2002). Controlling methane has been shown to be a win-win, benefiting both climate and air quality (Shindell et al., 2012). From a preindustrial level of $722 \pm 25 \mathrm{ppb}$ (Etheridge et al., 1998; Dlugokencky et al., 2005), methane has increased by a factor of $\sim 2.5$ to a value of $1857 \pm 1 \mathrm{ppb}$ in 2018 (Dlugokencky et al., 2018), mostly due to anthropogenic activities (Dlugokencky et al., 2011). The global network of surface observations over the past 3-4 decades indicates that methane went through a period of rapid growth from the 1980 s to 1990 s, nearly stabilized from 1999 to 2006 , 
and then renewed its rapid growth. Here, we estimate the methane budget and explore the contributions of methane sources and sinks to its observed trends and variability during 1980-2017.

Methane is emitted into the atmosphere from both anthropogenic activities (e.g., agriculture, energy, industry, transportation, waste management, and biomass burning) and natural processes (e.g., wetland, termites, oceanic and geological processes, and volcanoes), and it is removed from the atmosphere mainly by reaction with hydroxyl radical $(\mathrm{OH})$ in the troposphere, with lesser contributions to destruction by reactions with excited atomic oxygen $\left(\mathrm{O}\left({ }^{1} \mathrm{D}\right)\right)$ and atomic chlorine $(\mathrm{Cl})$ in the stratosphere and uptake by soils (Saunois et al., 2016). Measurements of the global distribution of surface methane beginning in 1983 have revealed that atmospheric methane approached steady state during 1983-2006 and has renewed its growth since then. During 1983-2006, methane growth rates decreased from $12 \mathrm{ppbyr}^{-1}$ during 1984-1991 to $5 \mathrm{ppbyr}^{-1}$ during 1992-1998 (Nisbet et al., 2014; Dlugokencky et al., 2018) and to $0.7 \pm 0.6 \mathrm{ppbyr}^{-1}$ during 1999-2006 (Dlugokencky et al., 2018). After 2006, methane started increasing again with a growth rate of $5.7 \pm$ $1.2 \mathrm{ppbyr}^{-1}$ in 2007-2013 and reached $12.6 \pm 0.5 \mathrm{ppbyr}^{-1}$ in 2014 and $10.0 \pm 0.7 \mathrm{ppb} \mathrm{yr}^{-1}$ in 2015 (Nisbet et al., 2016; Dlugokencky et al., 2018). While anthropogenic activities are widely considered responsible for the long-term methane increase since preindustrial times (Dlugokencky et al., 2011), there is no consensus on the drivers for the methane stabilization during 1999-2006 and renewed growth since 2007. Previous studies have attributed the stabilization during 1999 2006 to the combined effects of increased anthropogenic emissions with decreased wetland emissions (Bousquet et al., 2006), decreased fossil fuel emissions (Dlugokencky et al., 2003; Simpson et al., 2012; Schaefer et al., 2016) or rice paddies emissions (Kai et al., 2011), stable emissions from microbial and fossil fuel sources (Levin et al., 2012), or variations in methane sinks (Rigby et al., 2008; Montzka et al., 2011; Schaefer et al., 2016). The observed renewed growth since 2007 has been explained alternatively through increases in tropical emissions (Houweling et al., 2014; Nisbet et al., 2016) such as agricultural emissions (Schaefer et al., 2016; Patra et al., 2016) and tropical wetland emissions (Bousquet et al., 2011; Maasakkers et al., 2019), increases in fossil fuel emissions (Rice et al., 2016; Worden et al., 2017), decreases in sources compensated by decreases in sinks due to OH levels (Turner et al., 2017; Rigby et al., 2017), or a combination of changes in different sources such as increases in fossil, agriculture, and waste emissions with decreases in biomass burning emissions (Saunois et al., 2017). These different explanations reflect limitations in our understanding of recent changes in methane and its budget.

Previous work has generally combined observations of methane and its isotopic composition $\left({ }^{13} \mathrm{CH}_{4}\right)$ with inverse models (top-down), process-based models (bottom-up), or box models to estimate methane emissions and sinks and their variability (Bousquet et al., 2006; Monteil et al., 2011; Rigby et al., 2012; Kirschke et al., 2013; Ghosh et al., 2015; Schwietzke et al., 2016; Schaefer et al., 2016; Nisbet et al., 2014, 2016; Dalsøren et al., 2016; Turner et al., 2017; Rigby et al., 2017). Inverse models use observations to derive emissions, but usually prescribe climatological $\mathrm{OH}, \mathrm{O}\left({ }^{1} \mathrm{D}\right)$, and $\mathrm{Cl}$ levels or loss rates (e.g., Rice et al., 2016; Tsuruta et al., 2017). Box models, on the other hand, use methane observations together with those of other proxy chemicals (e.g., ${ }^{13} \mathrm{C} /{ }^{12} \mathrm{C}$ ratio, ethane, carbon monoxide, methyl chloroform) to provide information on the global methane budget (e.g., Schaefer et al., 2016; Turner et al., 2017) but lack information on spatial variability or regional characteristics. With process-based models (e.g., wetlands) and inventories representing different source types (e.g., fossil fuel emissions) to drive chemical transport models, the bottom-up approach is able to estimate the methane budget for all individual sources and sinks. However, without observational constraints, there is considerable uncertainty in the total methane emissions derived from a combination of independent bottom-up estimates (Saunois et al., 2016).

Bottom-up global Earth system models (ESMs) that realistically simulate the physical, chemical, and biogeochemical processes, as well as interactions and feedbacks among these processes, are useful tools to characterize the global methane cycle and quantify the global methane budget and impacts on composition and climate. Dalsøren et al. (2016) investigated the evolution of atmospheric methane by driving a chemical transport model with bottom-up emissions. While their model results are able to match the observed time evolution of methane without emission adjustments, surface methane is largely underpredicted in their study. Ghosh et al. (2015) optimized bottom-up emissions to investigate methane trends; however, $\mathrm{OH}$ trends and interannual variability were not considered in their chemical transport model. Here, we apply a prototype of the full-chemistry version of the Geophysical Fluid Dynamics Laboratory (GFDL) new-generation Atmospheric Model, version 4.1 (AM4.1; Zhao et al., 2018a, b; Horowitz et al., 2020) to investigate the evolution of methane over 1980-2017. Our main objectives are to improve the representation of methane in GFDL-AM4.1, to comprehensively evaluate the model performance of methane predictions with an improved representation of the methane budget, and to investigate possible drivers of the methane trends and variability. This paper is structured as follows: Sect. 2 describes the modeling approach, emission inventories, and observations used for model evaluation. Results of the model evaluation, global methane budget analysis, and model sensitivities are presented in Sect. 3. Finally, Sect. 4 summarizes the results and discusses the implication of these results. 


\section{Methodology and data}

\subsection{Model description and initialization}

We use a prototype version of the new-generation GFDL chemistry-climate model, GFDL-AM4.1 (Zhao et al., 2018a, b; Horowitz et al., 2020). A detailed description of the physics and dynamics in AM4.1 is provided by Zhao et al. $(2018 \mathrm{a}, \mathrm{b})$. The version of AM4.1 with full interactive chemistry used in this work is described by Schnell et al. (2018). In its standard form, this model setup consists of a cubed-sphere finite-volume dynamical core with a horizontal resolution of $\sim 100 \mathrm{~km}$ and 49 vertical levels extending from the surface up to $\sim 80 \mathrm{~km}$. The model's lowermost level is approximately $30 \mathrm{~m}$ thick. The chemistry and aerosol physics in this model have been updated from the previous version (GFDL-AM3; Naik et al., 2013a), as described by Mao et al. (2013a, b) and Paulot et al. (2016). There are a total of 102 advected gas tracers and 18 aerosol tracers, 44 photolysis reactions, and 205 gas-phase reactions included in the chemical mechanism in this version of AM4.1 to represent tropospheric and stratospheric chemistry.

The standard AM4.1 configuration uses global annualmean methane concentrations as a lower boundary condition to simulate the atmospheric distribution of methane. This modeling framework does not allow for the full characterization of the drivers of methane trends and variability, nor does it capture latitudinal or seasonal variations in methane. To overcome this issue, we updated AM4.1 to be driven by methane emissions. Table 1 provides information on the methane emission datasets used in this work. Our initial estimates of surface emissions from anthropogenic sources including agriculture (AGR), energy production (ENE), industry (IND), road transportation (TRA), residential, commercial, and other sectors (RCO), waste (WST), and international shipping (SHP) - are from the Community Emissions Data System (CEDS, version 2017-05-18; Hoesly et al., 2018) developed in support of the Coupled Model Intercomparison Project Phase 6 (CMIP6) for 1980-2014. Emissions for 2015-2017 are from a middle-of-the-road scenario of Shared Socioeconomic Pathways targeting a forcing level of $4.5 \mathrm{~W} \mathrm{~m}^{-2}$ (SSP2-4.5), developed in support of the ScenarioMIP experiment within CMIP6 (Gidden et al., 2019). Biomass burning (BMB) emissions are from van Marle et al. (2017) for 1980-2014 and from SSP2-4.5 for 2015-2017, and they are vertically distributed over seven ecosystemdependent altitude levels between the surface and $6 \mathrm{~km}$ above the surface, following the methodology of Dentener et al. (2006). Anthropogenic and biomass burning emissions are represented by monthly gridded emissions including seasonal and interannual variability. Natural emissions include wetland (WET) emissions from the WetCHARTs version 1.0 inventory (Bloom et al., 2017), ocean (OCN) emissions from Brasseur et al. (1998) with nearshore methane fluxes from Lambert and Schmidt (1993) and Patra et al. (2011), termites
(TMI) from Fung et al. (1991), and mud volcanoes (VOL) from Etiope and Milkov (2004) and Patra et al. (2011). Wetland emissions and ocean emissions are climatological monthly means without interannual variability. The remaining natural emissions are based on a climatological annual mean (repeated every month without seasonal variability). Time series of the total emissions and emissions from major sectors over 1980-2017 are shown in Fig. 1. Trends in total emissions are primarily driven by trends in ENE, AGR, and WST emissions. Although wetlands are in reality a major contributor to interannual variability in methane emissions (Bousquet et al., 2006; Kirschke et al., 2013), our use of climatological wetland emissions causes the interannual variability in our methane emissions to be dominated by BMB emissions. Anthropogenic and biomass burning emissions of other short-lived species also follow the CEDS and SSP2-4.5 inventories. Natural emissions of other short-lived species are from Naik et al. (2013a). Biogenic isoprene emissions are calculated interactively following Guenther et al. (2006).

The methane sinks considered in AM4.1 include oxidation by $\mathrm{OH}, \mathrm{Cl}$, and $\mathrm{O}\left({ }^{1} \mathrm{D}\right)$ and dry deposition. Since the model does not represent tropospheric halogen chemistry, it does not consider removal of methane by $\mathrm{Cl}$ in the troposphere, a sink that remains poorly constrained (Hossaini et al., 2016; Gromov et al., 2018; Wang et al., 2019). The dry deposition flux of methane is estimated based on a monthly climatology of deposition velocities (Horowitz et al., 2003) calculated by a resistance-in-series scheme (Wesely, 1989; Hess et al., 2000) and used to mimic methane loss by soil uptake, which accounts for about $5 \%$ of the total methane sink (Kirschke et al., 2013; Saunois et al., 2016).

In this work, we included 12 additional methane tracers tagged by source sector to attribute methane from agriculture (CH4AGR), energy (CH4ENE), industry (CH4IND), transportation (CH4TRA), residents (CH4RCO), waste (CH4WST), shipping (CH4SHP), biomass burning (CH4BMB), ocean (CH4OCN), wetland (CH4WET), termites (CH4TMI), and mud volcanoes (CH4VOL). The tracers are emitted from corresponding sources and undergo the same chemical and transport pathways as the full $\mathrm{CH}_{4}$ tracer. For analysis, we combine CH4IND, CH4TRA, CH4RCO, and CH4SHP as other anthropogenic tracers (i.e., CH4OAT), and we combine $\mathrm{CH} 4 \mathrm{OCN}, \mathrm{CH} 4 \mathrm{TMI}$, and $\mathrm{CH} 4 \mathrm{VOL}$ as other natural tracers (i.e., CH4ONA).

Initially the model was spun up in a 50-year run with repeating 1979 emissions driven by 1979 sea surface temperatures and sea ice until stable atmospheric burdens of methane and tagged tracers were obtained. After spin-up, several sets of simulations were conducted for 1980-2017 to quantify the methane budget and investigate the impacts of changes in methane sources and sinks on methane abundance (see Sect. 2.3). All model simulations are forced with interannually varying sea surface temperatures and sea ice from Taylor et al. (2000), prepared in support of the CMIP6 Atmospheric Model Intercomparison Project (AMIP) simulations. Hori- 
Table 1. Emission inventories used in this study.

\begin{tabular}{llll}
\hline Source category & Database & Temporal variability & References \\
\hline \multirow{2}{*}{ Anthropogenic } & CEDS v2017-05-18 & 1980-2014 monthly data & Hoesly et al. (2018) \\
\cline { 2 - 4 } & SSP2-4.5 & 2015-2017 monthly data & Gidden et al. (2019) \\
\hline \multirow{2}{*}{ Wetlands } & BB4MIP & 1980-2014 monthly data & van Marle et al. (2017) \\
\cline { 2 - 4 } & SSP2-4.5 & 2015-2017 monthly data & Gidden et al. (2019) \\
\hline Ocean & MOZART & $\begin{array}{l}\text { Climatological monthly mean (with } \\
\text { seasonal variability) for 1980-2017 }\end{array}$ & Bloom et al. (2017) \\
\hline Nearshore & TransCom-CH 4 & $\begin{array}{l}\text { Climatological annual mean (no } \\
\text { seasonal variability) for 1980-2017 }\end{array}$ & Lambert and Schmidt (1993), Patra et al. (2011) \\
\hline Termites & NASA-GISS & $\begin{array}{l}\text { Climatological annual mean (no } \\
\text { seasonal variability) for 1980-2017 }\end{array}$ & Fung et al. (1991) \\
\hline Mud volcanoes & TransCom-CH 4 & $\begin{array}{l}\text { Climatological annual mean (no } \\
\text { seasonal variability) for 1980-2017 }\end{array}$ & Etiope and Milkov (2004), Patra et al. (2011) \\
\hline
\end{tabular}

zontal winds are nudged to the National Centers for Environmental Prediction (NCEP) reanalysis (Kalnay et al., 1996) using a pressure-dependent nudging technique (Lin et al., 2012).

\subsection{Observations}

We evaluate the simulated methane dry-air mole fraction (DMF) against a suite of ground-based and aircraft observations to thoroughly evaluate the model-simulated spatial and temporal distribution of methane. To evaluate surface $\mathrm{CH}_{4}$, we use measurements from a globally distributed network of air sampling sites maintained by the Global Monitoring Division (GMD) of the Earth System Research Laboratory at the National Oceanic and Atmospheric Administration (NOAA) (Dlugokencky et al., 2018). The global estimates are based on spatial and temporal smoothing of $\mathrm{CH}_{4}$ measurements from 45 surface marine boundary layer (MBL) sites. Locations of the MBL sites are shown in Fig. S1 in the Supplement, and information for each MBL site is listed in Table S1 in the Supplement. First, the average trend and seasonal cycle are approximated for each sampling site by fitting a secondorder polynomial and four harmonics to the data. We characterize deviations from this average behavior by transforming the residuals to frequency domain, then multiplying by a low-pass filter (Thoning et al., 1989; Thoning, 2019). Zonal and global averages are determined by extracting values at synchronized times steps from the smoothed fits to the data, then fitting another curve as a function of latitude (Tans et al., 1989). We divide these fits into sine (latitude) $=0.05$ intervals, which define a matrix of zonally averaged $\mathrm{CH}_{4}$ as a function of time and latitude. The same sampling and pro- cessing approach (Thoning et al., 1989; Tans et al., 1989) is applied to the simulated monthly mean methane DMF to calculate global and zonal averages to facilitate consistent model-observation comparison. In addition to the comparison with global estimates from MBL sites, we also evaluate model performance at individual GMD sites to investigate regional emission representation. For site-specific evaluation, we sample the model grid cell at the location of the corresponding site and at the model layer with height closest to the altitude of the corresponding site.

To investigate background tropospheric methane variability, we compare the simulated vertical profiles with aircraft measurements from the High-performance Instrumented Airborne Platform for Environmental Research (HIAPER) Poleto-Pole observation (HIPPO) campaigns from January 2009 to September 2011 (Wofsy et al., 2011, 2012). A total of 787 profiles were flown during five campaigns with continuous profiling between approximately 150 and $8500 \mathrm{~m}$ altitudes, but also including many profiles up to $14 \mathrm{~km}$ altitude. For each HIPPO mission, we spatially sample the model consistent with the observations and average the model for the months of the campaign to create climatological monthly means.

\subsection{Simulation design}

We conduct several sets of hindcast simulations for 1980 2017, as listed in Table 2, to quantify the methane budget and investigate the contributions of sources and sinks to the trend and variability of methane. The model simulation using the initial methane emissions inventory $\left(E_{\text {init }}\right)$ described in Sect. 2.1 was found to largely underestimate the methane 

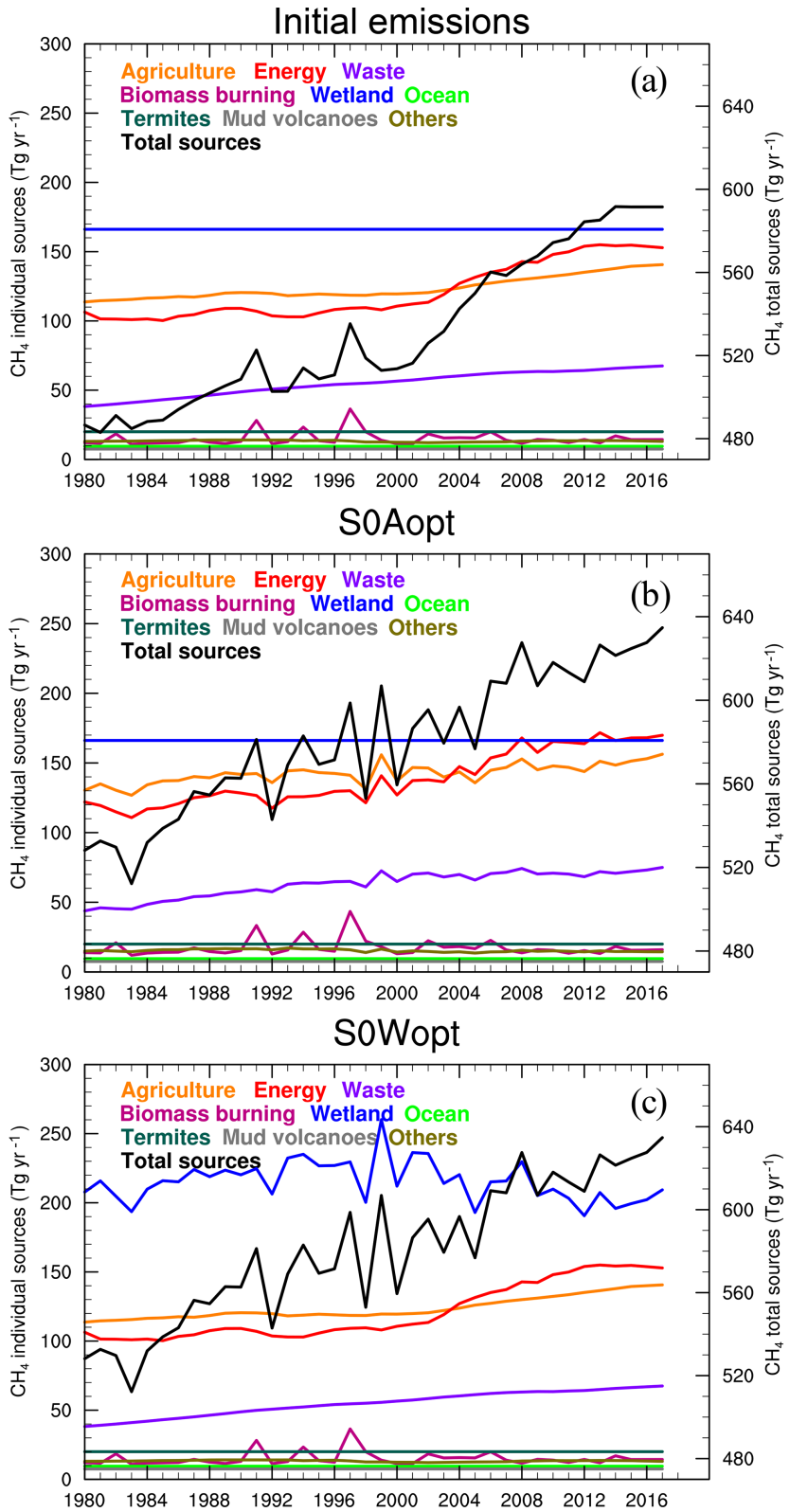

Figure 1. Time series of methane emissions from the initial methane inventories (a) and optimized methane emissions on anthropogenic sectors (S0Aopt, b) and wetland sectors (S0Wopt, c) for the period of 1980-2017. The emissions for major sectors are shown on the left $y$ axis, including the agriculture sector, energy production sector, waste sector, biomass burning sector, wetland sector, ocean and nearshore fluxes, termites, mud volcanoes, and other sources (i.e., industrial processes, surface transportation, international shipping, residential, commercial, and others). The total methane emissions from the initial emission inventories and optimization (black line) are shown on the right $y$ axis.
Table 2. List of simulations conducted using GFDL-AM4.1 to explore trends and variability in methane.

\begin{tabular}{ll}
\hline Simulations & Description \\
\hline S0Aopt & $\begin{array}{l}\text { Standard AM4.1 configuration, but with opti- } \\
\text { mized anthropogenic emissions for 1980-2017 }\end{array}$ \\
\hline S0Wopt & $\begin{array}{l}\text { Standard AM4.1 configuration, but with opti- } \\
\text { mized wetland emissions for 1980-2017 }\end{array}$ \\
\hline S0A06 & $\begin{array}{l}\text { S0Aopt emissions for 1980-2005, with repeat- } \\
\text { ing 2006 S0Aopt anthropogenic emissions for }\end{array}$ \\
& $\begin{array}{l}\text { 2006-2014 and adjusting wetland emissions for } \\
\text { 2006-2014 to ensure the total emissions are the } \\
\text { same as optimized totals }\end{array}$ \\
\hline S0Comb & $\begin{array}{l}\text { S0Aopt emissions for 1980-2005 and S0Wopt } \\
\text { emissions for 2006-2014 }\end{array}$ \\
\hline S1Wopt & $\begin{array}{l}\text { AM4.1 configuration with low OH levels } \\
\text { (LNO } x \text { emissions scaled by a factor of 0.5) and } \\
\text { optimized wetland emissions for 1980-2017 }\end{array}$ \\
\hline S2Wopt & $\begin{array}{l}\text { AM4.1 configuration with high OH levels } \\
\text { (LNO } x \text { emissions scaled by a factor of 2) and } \\
\text { optimized wetland emissions for 1980-2017 }\end{array}$ \\
\hline
\end{tabular}

DMF by 126 ppb (see Figs. S2 and S3 in the Supplement). Assuming that this mismatch is due to a bias in the simulated methane budget, we can either increase methane sources or decrease methane sinks to match the observations. We perform several optimization simulations that explore the sensitivity of methane to uncertainties in emissions of methane and levels of $\mathrm{OH}$, the dominant sink for methane. Because $\mathrm{OH}$ trends and variability depend on a number of factors, including temperature, water vapor, $\mathrm{O}_{3}$, and emissions of nitrogen oxide $\left(\mathrm{NO}_{x}\right)$, carbon monoxide $(\mathrm{CO})$, and volatile organic compounds (VOCs), it is not straightforward to perturb $\mathrm{OH}$. Previous work has shown that interannual variability of global $\mathrm{OH}$ is highly correlated with $\mathrm{NO}_{x}$ from lightning (Fiore et al., 2006; Murray et al., 2013). Therefore, we apply scaling factors to lightning $\mathrm{NO}_{x}\left(\mathrm{LNO}_{x}\right)$ emissions to indirectly adjust $\mathrm{OH}$ levels without influencing its variability. The $\mathrm{LNO}_{x}$ emissions are calculated interactively as described by Horowitz et al. (2003) as a function of subgrid convection parameterized in the model. The climatological global mean $\mathrm{LNO}_{x}$ emission simulated by standard AM4.1 is about $3.6 \mathrm{Tg} \mathrm{Nyr}^{-1}$, within the range of $2-8 \mathrm{Tg} \mathrm{Nyr}^{-1}$ estimated by previous studies (e.g., Schumann and Huntrieser, 2007). We additionally apply scaling factors (e.g., 0.5 and 2.0) to $\mathrm{LNO}_{x}$ emissions, producing $\mathrm{LNO}_{x}$ at the lower and upper limits of the estimated range for sensitivity simulations described below.

We test the sensitivity of simulated methane to changes in $\mathrm{OH}$ using (1) standard $\mathrm{OH}$ levels simulated by AM4.1 (referred to as "S0"), (2) low OH levels via application of a scaling factor of 0.5 to the default $\mathrm{LNO}_{x}$ emission calculations 
(referred to as "S1"), and (3) high $\mathrm{OH}$ levels via application of a factor of 2 to the default $\mathrm{LNO}_{x}$ emission calculation (referred to as "S2"). For each OH option, we begin with initial methane emissions and then optimize global total emissions as described below to match simulated methane with surface observations. Different $\mathrm{OH}$ levels lead to different estimations of the optimized total emissions, which provide a measure of uncertainties in our optimized total methane emissions.

The estimates of optimized emissions are based on comparison of simulated surface methane with NOAA GMD MBL observations. We apply a simple mass balance approach to optimize global total methane emissions, following the methodology of Ghosh et al. (2015). In this approach, we calculate an increment $\Delta E$, by which global emissions need to be modified for each year. We do so by converting the differences in surface methane DMFs between observations and model estimates to the differences in methane burden growth rate and in total methane loss. We iterate the optimization process a couple of times to account for the methane-OH feedback until the simulated surface methane DMF matches the observations. Unlike inverse modeling studies (Houweling et al., 2017), we do not optimize emissions for each grid cell. Instead, we uniformly scale emissions for particular sectors (as described below) globally for each year by the rate of the optimized emission total $\left(E_{\mathrm{opt}}=E_{\text {init }}+\Delta E\right)$ to the initial emissions ( $\left.E_{\text {init }}\right)$. We assume that the spatial distribution of methane emissions from the initial emission inventories is the best available information we have. Considering the large uncertainties in the anthropogenic and wetland emissions, we perform two simulations for the standard (S0) $\mathrm{LNO}_{x}$ scenario, in which we achieve the optimized emission totals by scaling either anthropogenic and biomass burning sources only (referred to as "Aopt") or the wetland sector only (referred to as "Wopt"). The purpose of conducting these simulations is to investigate the impact of optimizing emissions from different sectors on methane predictions. For the Aopt case, eight anthropogenic sectors (i.e., AGR, ENE, IND, TRA, RCO, WST, SHP, and BMB) are uniformly scaled by the ratio of $\Delta E$ to total anthropogenic emissions $\left(\Delta E / E_{\text {anthro. }}\right)$, keeping the fractions of individual sources unchanged. For the Wopt case, wetland emissions are rescaled to increase this source by $\Delta E$. For $\mathrm{S} 1$ and $\mathrm{S} 2$ scenarios, we scale the wetland sector only. The total $E_{\mathrm{opt}}$ emissions are the same for both Aopt and Wopt cases. Time series of optimized total emissions and emissions from major sectors from S0Aopt and S0Wopt over 1980-2017 are shown in Fig. 1. As shown in Fig. 1, the emission optimization to match observations resulted in higher interannual variability in total emissions than in the initial emissions. Although the interannual variability of methane emissions is mainly dominated by that from wetland and biomass burning, it could also exist in anthropogenic emissions due to the dependence of microbial methane sources, such as rice paddies, on soil temperature and precipitation (e.g., Knox et al., 2016). Because the purpose of S0Aopt is to investigate the role of changes in total anthropogenic emissions (including BMB) rather than individual sectors, we applied this interannual variability to all anthropogenic sectors, which we acknowledge introduces some unrealistic interannual variability in the anthropogenic emissions. We chose this experimental construct to limit the number of sensitivity simulations.

Based on evidence from $\delta^{13} \mathrm{CH}_{4}$, recent studies suggest increasing wetland emissions may be responsible for the renewed growth of methane (Dlugokencky et al., 2009; Nisbet et al., 2016). We perform two additional sensitivity simulations to test the possibility of wetland emissions driving the renewed methane growth during 2006-2014. One simulation is driven by repeating 2006 S0Aopt anthropogenic and biomass burning emissions for 2006-2014 but adjusting wetland emissions to ensure that the total methane emissions are the same as in S0Wopt (or S0Aopt), which would imply that the increases in methane emissions are only due to the increases in wetland emissions. This sensitivity simulation is referred to as "S0A06". Another sensitivity simulation is driven by a combination of emissions for S0Aopt and S0Wopt as follows: S0Aopt emissions for 1980-2005 and S0Wopt emissions for 2006-2014. This simulation is referred to as "SOComb".

\section{Results and discussions}

\subsection{Model evaluation}

The detailed model evaluation for S0Aopt and S0Wopt is discussed below. We first evaluate the mean climatological spatial distribution and seasonal variability simulated by the model and then evaluate the trends and variability.

\subsubsection{Climatological evaluation}

Figure 2 shows the model bias and correlation coefficient of simulated climatological mean surface methane DMF against NOAA GMD surface observations (Dlugokencky et al., 2018) for 1983-2017. The mean seasonal cycle at individual GMD sites is shown in Fig. S4 in the Supplement. GMD sites with at least 20 years of observations are selected for model climatological evaluation. Information about these sites is shown in Table S2 in the Supplement. As shown in Fig. 2a, simulations with optimization of either anthropogenic (S0Aopt) or wetland (SOWopt) emissions are generally able to reproduce surface methane DMF with model biases within $\pm 30 \mathrm{ppb}$ at most sites. Both S0Wopt and S0Aopt simulate methane DMF relatively well over the Southern Hemisphere. Going from south to north, the low bias in methane DMF decreases and becomes a high bias over the tropics. Simulated methane in both S0Aopt and S0Wopt is biased moderately high over the tropical Pacific Ocean (by up to $\sim 40 \mathrm{ppb}$ ), indicating possible overestimation of methane emissions over the tropics and possible underes- 

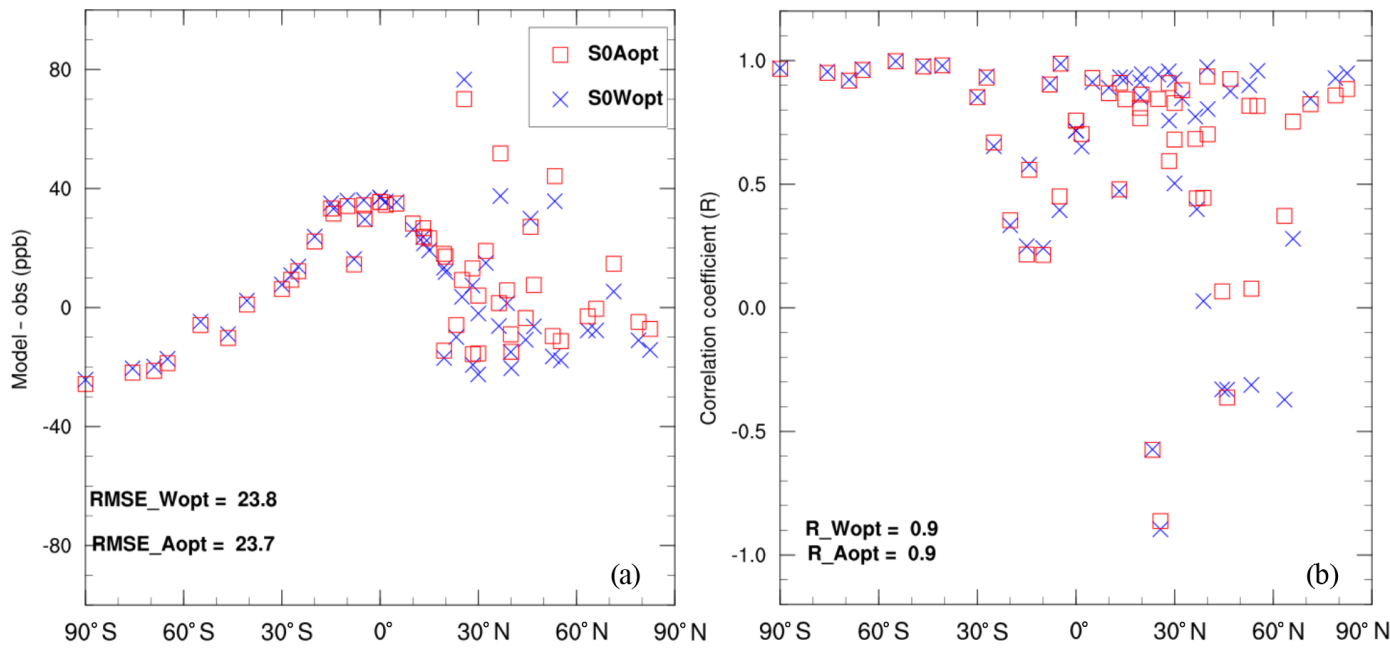

Figure 2. Model bias (a) and correlation coefficient (b) of simulated climatological mean surface methane concentrations against NOAA GMD observations for the 1983-2017 time period. GMD sites with at least 20-year observations are selected for model climatological evaluation. In panel (a), each red square or blue "X" represents model mean bias by S0Aopt or S0Wopt at the corresponding GMD site. Root-mean-square error (RMSE) is shown for all the GMD sites in panel (a). In panel (b), each red square or blue " $\mathrm{X}$ " represents correlation of climatological seasonal variability by S0Aopt or S0Wopt at the corresponding GMD site. Spatial correlation $(R)$ is shown for all the GMD sites in panel (b).

timation in tropical $\mathrm{OH}$ levels. Large positive biases occur at Key Biscayne (KEY, $25.7^{\circ} \mathrm{N}, 80.2^{\circ} \mathrm{W}$ ) and Mace Head $\left(\mathrm{MHD}, 53.3^{\circ} \mathrm{N}, 9.9^{\circ} \mathrm{W}\right.$ ) for both S0Wopt and S0Aopt, likely due to a model sampling bias, with the model grid box overlapping land while samples are collected with onshore winds. Over middle and high latitudes of the Northern Hemisphere, the simulated surface methane DMF shows low and high biases at individual sites, possibly due in part to uncertainties in the local emissions. As shown in Fig. 2b, both S0Aopt and S0Wopt are able to capture the methane seasonal cycle at most sites (with a correlation coefficient $(R)$ larger than 0.5 for about $80 \%$ of sites). Both S0Aopt and S0Wopt are able to reproduce the methane seasonal cycle over the Southern Hemisphere. However, both S0Aopt and S0Wopt show poor performance in the seasonal cycle over the southern tropical Pacific Ocean, with $R<0.5$ (e.g., POCS10 and POCS15 in Fig. S4 in the Supplement), but they show good performance in the seasonal cycle over the northern tropical Pacific Ocean, with $R=0.9$ (e.g., POCN05, POCN10, and POCN15 in Fig. S4). Poor performance also exists at a few sites in middle and high northern latitudes (e.g., Terceira Island, Ulaan-Uul, Park Falls, Mace Head, and Stórhöfði shown in Fig. S4), mainly due to overestimates of methane during summer. The major differences in simulated methane seasonal cycles between S0Aopt and SOWopt occur over the Northern Hemisphere, with slightly better performance by SOWopt over the Pacific Ocean and by S0Aopt over continental sites (e.g., Ulaan-Uul, Mt. Waliguan, Wendover, and Niwot Ridge). Uncertainties in the seasonality of methane emissions, $\mathrm{OH}$ abundances, and long-range transport could lead to biases in the seasonal cycle. In general, both S0Aopt and S0Wopt are able to capture the methane latitudinal gradient (e.g., $R=0.9$ ). This suggests that the spatial distribution of methane in emissions is reasonable on the large scale despite uncertainties in representing local sources.

To investigate background tropospheric methane variability, Fig. 3 shows the bias in the simulated vertical distribution of methane with respect to HIPPO observations for the S0Aopt and S0Wopt simulations. S0Aopt and S0Wopt simulations produce very similar methane profiles. Both S0Aopt and SOWopt match observed methane profiles very well over the Southern Hemisphere. Compared to HIPPO measurements, methane in both simulations is consistently high over the tropical Pacific Ocean (by up to $\sim 50 \mathrm{ppb}$ ) from the surface to $700 \mathrm{mb}$ during all HIPPO campaigns. These biases decrease with altitude and decrease with latitude except for in summer. In the Northern Hemisphere, both S0Wopt and S0Aopt simulations capture observed methane from near the surface to $700 \mathrm{mb}$, but are generally biased low, except in summer when they are biased high, especially at midlatitudes. Midlatitude background methane is affected by both high-latitude and low-latitude air masses on synoptic scales. Biases over these regions could result from many processes (e.g., overestimation of the summer emissions, insufficient $\mathrm{OH}$ levels, and model transport). In general, the relative differences between the simulated methane profiles and HIPPO measurements are within $2 \%$ over most regions, demonstrating the capability of the improved GFDL-AM4.1 for simulating tropospheric methane. 

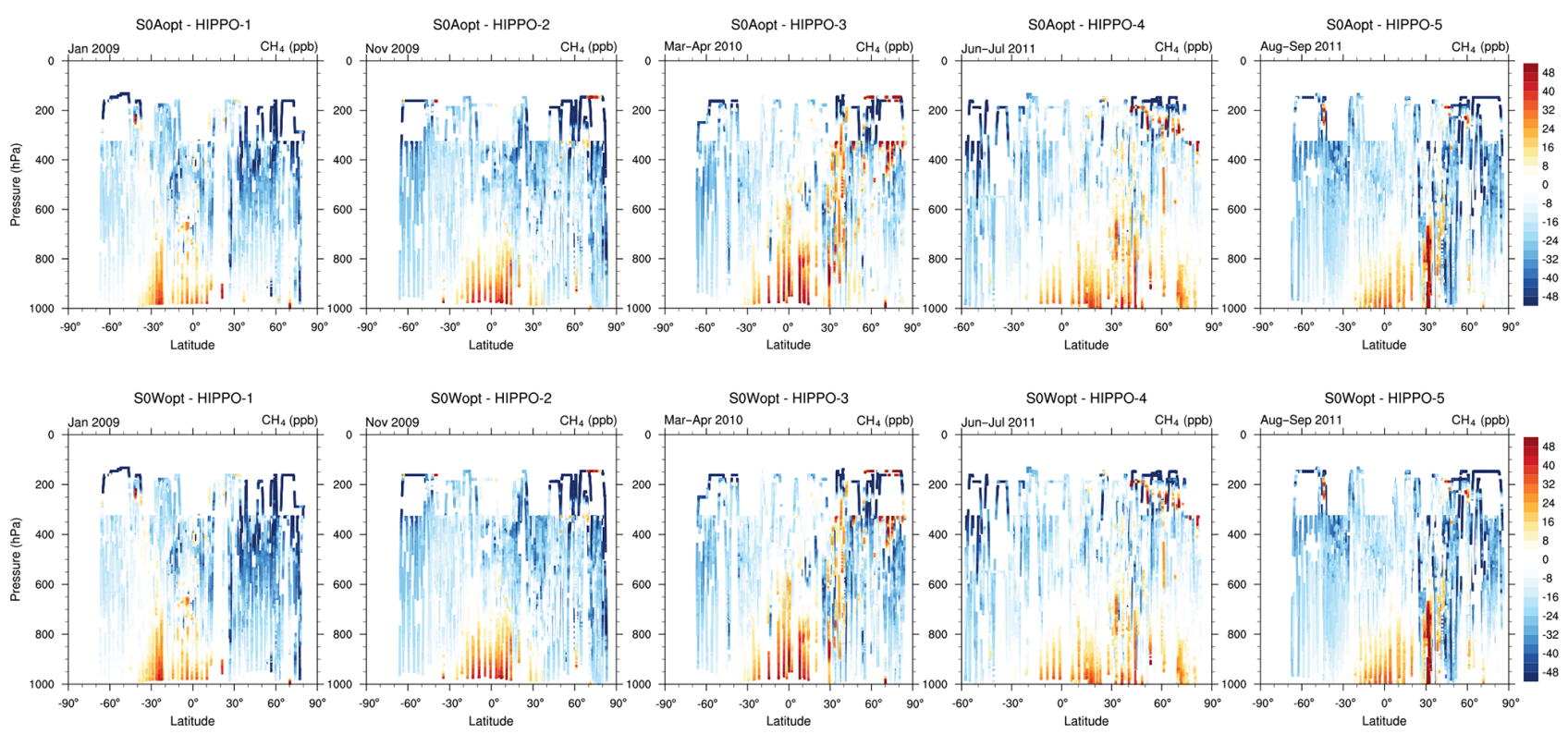

Figure 3. Comparison of vertical distribution of methane from S0Aopt and SOWopt simulations with measurements from individual HIPPO campaigns. Months of campaign are given at the top left of the individual plots.

\subsubsection{Time series evaluation}

As described in Sect. 2.2, we fit a function consisting of yearly harmonics and a polynomial trend, with fast Fourier transform and low-pass filtering of the residuals, to the monthly mean methane DMF (Thoning et al., 1989; Thoning, 2019) to estimate the time series and growth rates discussed below. The comparisons of simulated global mean background surface methane time series and growth rates to NOAA GMD observations are shown in Fig. 4. Both S0Wopt and S0Aopt predict similar global mean surface methane DMF, time series, and growth rates, since the global methane budget (emissions and sinks) is the same in the two simulations. SoWopt and S0Aopt are also able to reproduce global annual mean surface methane DMF (with root-meansquare error $(\mathrm{RMSE})=10.4 \mathrm{ppb}$ in SOWopt and $11.6 \mathrm{ppb}$ in S0Aopt) over 1983-2017, which is expected from emission optimization. Meanwhile, both simulations are able to reproduce the methane time series very well (with $R=1.0$ in both SOWopt and S0Aopt) over different latitude bands as shown in Fig. 4. The major discrepancies in surface methane DMF between model simulations and observations are mainly over low latitudes, especially the tropics, where the RMSE is greater than $20 \mathrm{ppb}$. Over the high northern latitudes, both S0Aopt and S0Wopt reproduce background methane DMF very well with RMSE less than $10 \mathrm{ppb}$. Over the high southern latitudes, both S0Aopt and S0Wopt underestimate background methane DMF by up to $35 \mathrm{ppb}$ in the $1980 \mathrm{~s}$, which could be due in part to the fewer observational sites in the Southern Hemisphere used for emission optimization during this time period. In general, the agreement between the evolution of the simulated and observed global methane DMFs
Table 3. Comparisons of simulated methane growth rates (annual mean \pm standard deviation) with observed methane growth rates $\left(\mathrm{ppbyr}^{-1}\right)$.

\begin{tabular}{lrrrr}
\hline & $1984-1991$ & $1992-1998$ & $1999-2006$ & $2007-2017$ \\
\hline Observed & $11.7 \pm 1.4$ & $5.5 \pm 3.5$ & $0.7 \pm 3.1$ & $7.0 \pm 2.7$ \\
S0Aopt & $13.7 \pm 3.2$ & $5.4 \pm 3.4$ & $1.3 \pm 4.1$ & $6.1 \pm 2.7$ \\
S0Wopt & $13.6 \pm 3.4$ & $5.4 \pm 3.6$ & $1.3 \pm 4.4$ & $6.1 \pm 2.6$ \\
\hline
\end{tabular}

increases our confidence in the optimized methane emission trends used in this work.

Table 3 summarizes methane growth rates during 19841991, 1992-1998, 1999-2006, and 2007-2017. S0Aopt and SoWopt simulate very similar methane growth rates as their emission totals are the same. During 1984-1991, both S0Aopt and S0Wopt slightly overestimate methane growth rates by $\sim 2 \mathrm{ppbyr}^{-1}$, possibly due to fewer available observations used for emission optimization during this time period than afterwards. After 1991, the simulated methane growth rates are in general comparable to the observations (with annual mean difference within $\pm 1 \mathrm{ppbyr}^{-1}$ ). The major discrepancies in the simulated methane growth rates and observations occur over the tropics and high northern latitudes as shown in Fig. 4. Over the tropics, both S0Aopt and S0Wopt overestimate methane growth rates (by about 5-10 ppb yr $^{-1}$ ) during 1984-1990 when there were limited observations available but are able to reproduce methane growth rates relatively well afterwards. Agreement of the methane growth rate is worse in the Northern Hemisphere than in the Southern Hemisphere, especially at high north- 

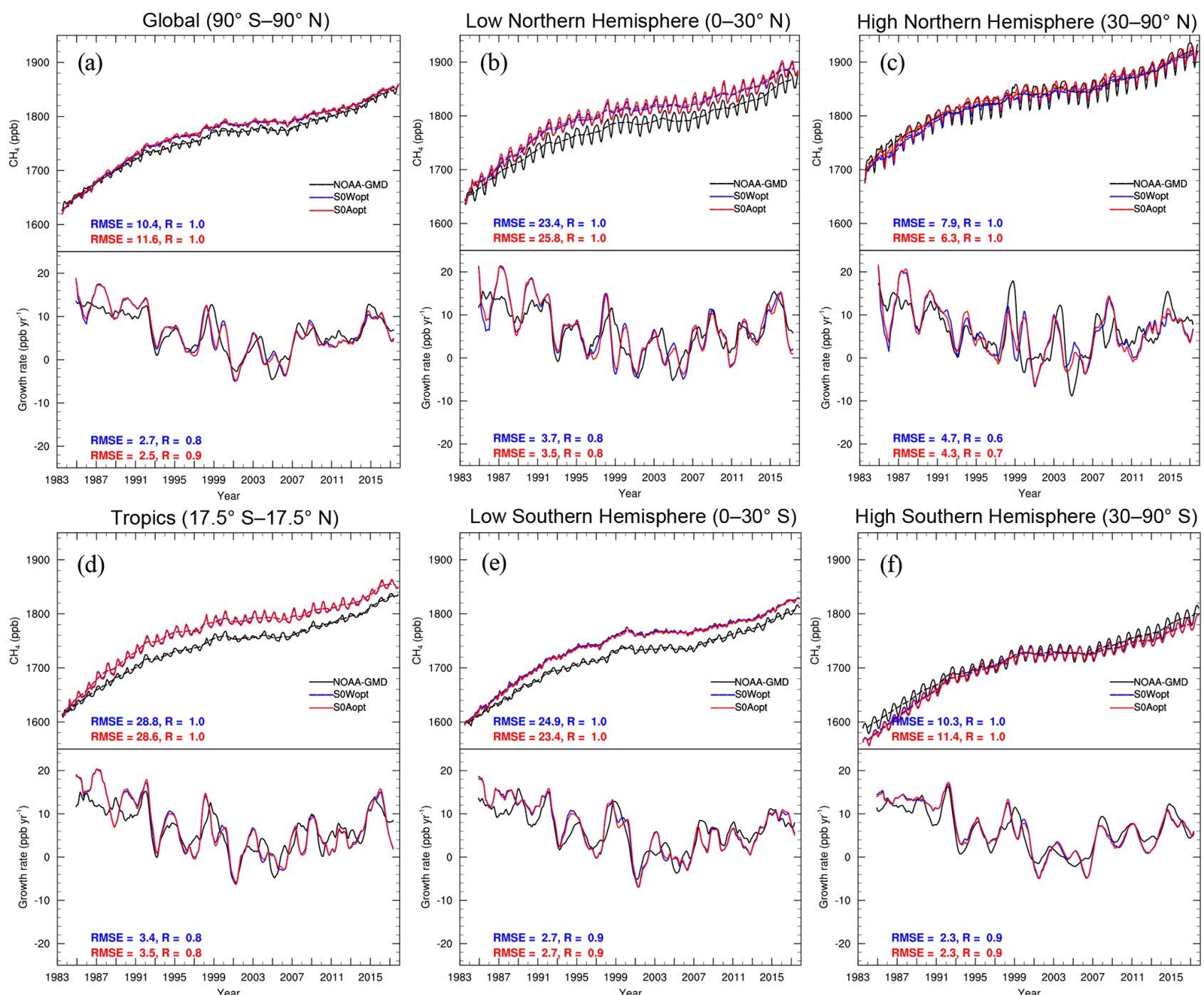

Figure 4. Comparison of GFDL-AM4.1 simulated methane concentrations and growth rates with NOAA GMD surface observations. For the upper plot in each panel, the dashed line represents smoothed trends (i.e., 12-month running mean) from deseasonalized monthly data. A meridional curve (Tans et al., 1989) was fitted through NOAA GMD site observations to get the latitudinal distribution of methane. A function fit consisting of yearly harmonics and a polynomial trend, with fast Fourier transform and low-pass filtering of the residuals is applied to the monthly mean methane DMF (Thoning et al., 1989; Thoning, 2019) to approximate the long-term trend. For the lower plot in each panel, the growth rates are calculated from the time derivative of the dashed line in the corresponding upper plot.

ern latitudes, mainly due to the large bias during 1984-1988 and a slight shift in peak growth (or peak decrease) during 1997-2005. The number of observational MBL sites does not provide adequate coverage of the globe, especially in the 1980s, which could have different impacts on the Northern Hemisphere and Southern Hemisphere when optimizing global total emissions. In general, S0Aopt estimates slightly better methane growth rates than S0Wopt, especially over $30-90^{\circ} \mathrm{N}$. The biases in methane growth rates also suggest a need to refine regional emissions.

S0Aopt and S0Wopt simulate very similar surface methane DMF, and their comparison with NOAA GMD observations at individual sites shows both simulations to be biased low over Southern Hemisphere sites, but the low bias decreases northward (Fig. S5 in the Supplement). The simulations are biased moderately high (by up to $\sim 40 \mathrm{ppb}$ ) over tropical regions (e.g., POCS15, POCS10, SMO, POCS05, POCNO0, CHR, and POCN05). These sites are mainly remote sites, and surface methane DMF represents background methane levels. The overestimates are likely due to overestimation of emissions over Southeast Asia (e.g., Saeki and Patra, 2017; Patra et al., 2016; Thompson et al., 2015), which could affect these remote sites through transport. However, the model predicts surface methane DMF relatively well at Ascension Island (ASC, $8^{\circ} \mathrm{S}, 14.4^{\circ} \mathrm{W}$ ), which is also a remote site without impacts from East Asia. The high biases 


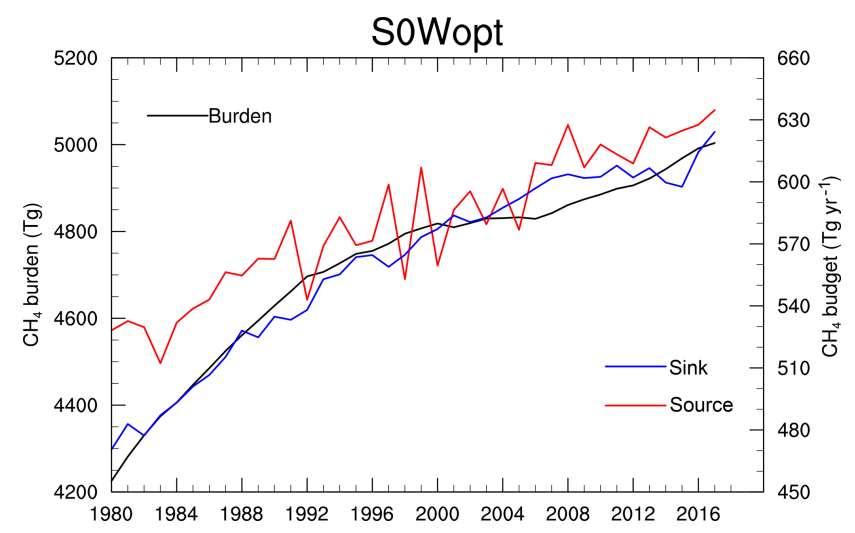

Figure 5. Time series of global methane burden (black line, left $y$ axis), methane sources (red line, right $y$ axis), and methane sinks (blue line, right $y$ axis) by SoWopt.

over the tropics suggest a need to improve regional emissions (e.g., Southeast Asia). Moderate overestimates also occur at Mahé (SEY, $\left.4.7^{\circ} \mathrm{S}, 55.5^{\circ} \mathrm{E}\right)$, a location that could be affected by air masses from polluted areas over the tropics and Northern Hemisphere. Over middle and high latitudes of the Northern Hemisphere, both S0Aopt and S0Wopt simulate surface methane DMF relatively well at most sites, except at Key Biscayne (KEY, $25.7^{\circ} \mathrm{N}, 80.2^{\circ} \mathrm{W}$ ), Tae-ahn Peninsula (TAP, $36.7^{\circ} \mathrm{N}, 126.1^{\circ} \mathrm{W}$ ), Park Falls (LEF, $45.9^{\circ} \mathrm{N}$, $113.7^{\circ} \mathrm{W}$ ), and Mace Head (MHD, 53.3 $\left.\mathrm{N}, 9.9^{\circ} \mathrm{W}\right)$. KEY, $\mathrm{MHD}$, and TAP are sampled under onshore winds, whereas LEF is affected by local sources and transport. The high biases at these sites could be due in part to model sampling bias (e.g., model grid box overlapping land while samples are collected at the coast with onshore winds) and uncertainties in local emissions (e.g., possible overestimation in the emissions over East Asia). In general, both S0Wopt and S0Aopt are able to reproduce the surface methane DMF and capture the monthly variations at most sites (e.g., with $R$ greater than 0.5 at $98 \%$ of total sites and with RMSE less than $30 \mathrm{ppb}$ at $74 \%$ of total sites). As shown in Fig. S5, S0Aopt in general better estimates methane time series and growth over low latitudes of the Southern Hemisphere (e.g., Tutuila) and middle to high latitudes of the Northern Hemisphere (e.g., Assekrem, Key Biscayne, Weizmann Institute of Science, Wendover, Niwot Ridge, Ulaan-Uul, Park Falls, Cold Bay, Ocean Station M, and Alert) than SOWopt. Based on the site-level comparisons between S0Wopt and S0Aopt, anthropogenic emissions over Southeast Asia are likely overestimated in both S0Aopt and S0Wopt, while they could be underestimated at Mt. Waliguan and Niwot Ridge in S0Wopt but be reasonably well represented in S0Aopt.

\subsection{Global methane budget}

Figure 5 shows time series of optimized total emissions, global sink, and global burden of methane based on S0Wopt.
Since global totals in the S0Aopt and S0Wopt simulations are very similar, we only show the budget for SoWopt. As depicted in Fig. 5, the simulated global methane burden steadily increases from 1980 to 1992 , with a growth rate of $39 \mathrm{Tg} \mathrm{yr}^{-1}$. During 1993-1998, the global methane burden growth slows with a growth rate of $16 \mathrm{Tg} \mathrm{gr}^{-1}$. The simulated growth rate in global methane burden decreases to $4 \mathrm{Tg} \mathrm{yr}^{-1}$ during 1999-2006 while it increases to $16 \mathrm{Tg} \mathrm{yr}^{-1}$ during 2007-2017 and reaches over $20 \mathrm{Tg} \mathrm{yr}^{-1}$ during 2014 2016. The changes in the global burdens are due to the imbalance between methane emissions and sinks. As shown in Fig. 5, the optimized emissions in general increase during 1980-2017, with an annual mean of $580 \pm 34 \mathrm{Tg} \mathrm{yr}^{-1}$ (mean \pm standard deviation), and show much larger interannual variability during 1991-1993 and 1997-2000, which is likely due to the strong El Niño events during 1991-1992 and 1997-1998 as well as the Mt. Pinatubo eruption in 1991 (Dlugokencky et al., 1996; Bousquet et al., 2006; Bândă et al., 2016). Although there is an overall increasing trend in total global emissions, growth in annual mean emissions has increased from the 1980s (with an annual emission growth rate of $3.9 \mathrm{Tg} \mathrm{yr}^{-1}$ ) to the $1990 \mathrm{~s}\left(4.4 \mathrm{Tg} \mathrm{yr}^{-1}\right)$, but decreased to $0.3 \mathrm{Tg} \mathrm{yr}^{-1}$ during 2000-2006, and increased again to $2.3 \mathrm{Tg} \mathrm{yr}^{-1}$ during 2007-2017. Interannual variability of the optimized emissions mainly results from interannual variability in simulated $\mathrm{OH}$ levels during emission optimization. Uncertainties in the interannual variability of simulated $\mathrm{OH}$ levels and therefore methane sinks could lead to uncertainties in the interannual variability of the optimized emissions.

Unlike methane emissions, the methane sink increases during 1980-2007, with relative stabilization during 20082014 but a resumed increase during 2015-2017. The annual mean methane sink during $1980-2017$ is $560 \pm 44 \mathrm{Tg} \mathrm{yr}^{-1}$ (mean \pm standard deviation). The trends in methane sink are affected by the changes in both methane and $\mathrm{OH}$ levels (assuming that other sinks are minor) and temperature. Figure 6 shows the tropospheric $\mathrm{OH}$ anomalies with respect to 1998-2007. An interesting finding is that AM4.1 predicts higher OH levels during 2008-2014 than 1998-2007 by $3.1 \%$, whereas previous studies applying multispecies inversion with a box-model framework (e.g., Rigby et al., 2017; Turner et al., 2017) suggest a decline in OH levels after 2007. However, a recent study by Naus et al. (2019) found a shift to a positive OH trend over 1994-2015 after applying bias corrections based on a 3-D chemical transport model to a similar box-model setup. In addition, $\mathrm{OH}$ levels simulated by AM4.1 decrease from 2013 to 2015 but increase again afterwards, leading to an increase in methane sinks during 2015-2017. As shown in Fig. 5, larger methane emissions than sinks during 1980-1998 lead to an increase in methane burden. A relative balance between methane sources and sinks during 1999-2006 leads to the methane stabilization. Compared to 1999-2006, both methane sources and sinks are greater during 2007-2017, but methane emissions outweigh sinks after 2007 , leading to renewed methane growth. 
Table 4. Global methane budget $\left(\mathrm{Tg} \mathrm{CH}_{4} \mathrm{yr}^{-1}\right)$ during 1980-2017.

\begin{tabular}{|c|c|c|c|c|c|c|}
\hline Period of time & 1980-1989 & 1990-1999 & 2000-2009 & 2008-2017 & 1999-2006 & 2007-2017 \\
\hline \multicolumn{7}{|l|}{ Sources $^{\mathrm{a}}$} \\
\hline Natural sources & $\begin{array}{l}203[203-282] \\
203[150-267]^{\mathrm{b}} \\
355[244-466]^{\mathrm{c}}\end{array}$ & $\begin{array}{l}203[203-297] \\
182[167-197]^{\mathrm{b}} \\
336[230-465]^{\mathrm{c}}\end{array}$ & $\begin{array}{l}203[203-288] \\
218[179-273]^{\mathrm{b}} \\
347[238-484]^{\mathrm{c}} \\
214[176-243]^{\mathrm{d}} \\
369[245-485]^{\mathrm{e}}\end{array}$ & $\begin{array}{l}203[203-277] \\
215[176-248]^{\mathrm{d}} \\
371[245-488]^{\mathrm{e}}\end{array}$ & 203 [203-297] & 203 [203-277] \\
\hline Natural wetlands & $\begin{array}{l}166[166-245] \\
167[115-231]^{b} \\
225[183-266]^{c}\end{array}$ & $\begin{array}{l}166[166-260] \\
150[144-160]^{\mathrm{b}} \\
206[169-265]^{\mathrm{c}}\end{array}$ & $\begin{array}{l}166[166-251] \\
175[142-208]^{\mathrm{b}} \\
217[177-284]^{\mathrm{c}} \\
180[153-196]^{\mathrm{d}} \\
147[102-179]^{\mathrm{e}}\end{array}$ & $\begin{array}{l}166[166-240] \\
178[155-200]^{\mathrm{d}} \\
149[102-182]^{\mathrm{e}}\end{array}$ & $166[166-260]$ & $166[166-240]$ \\
\hline Other natural sources & 37 & 37 & $\begin{array}{l}37 \\
35[21-47]^{\mathrm{d}} \\
222[143-306]^{\mathrm{e}}\end{array}$ & $\begin{array}{l}37 \\
37[21-50]^{\mathrm{d}} \\
222[143-306]^{\mathrm{e}}\end{array}$ & 37 & 37 \\
\hline Oceans & 9.5 & 9.5 & $\begin{array}{l}9.5 \\
18[2-40]^{c} \\
13[9-22]^{\mathrm{e}}\end{array}$ & 9.5 & 9.5 & 9.5 \\
\hline Termites & 20 & 20 & 20 & 20 & 20 & 20 \\
\hline Mud volcanoes & 7.5 & 7.5 & 7.5 & 7.5 & 7.5 & 7.5 \\
\hline Anthropogenic sources & $\begin{array}{l}289[289-368] \\
348[305-383]^{\mathrm{b}} \\
308[292-323]^{\mathrm{c}}\end{array}$ & $\begin{array}{l}311[311-405] \\
372[290-453]^{\mathrm{b}} \\
313[281-347]^{\mathrm{c}}\end{array}$ & $\begin{array}{l}340[340-425] \\
335[273-409]^{\mathrm{b}} \\
331[304-368]^{\mathrm{c}} \\
331[310-346]^{\mathrm{d}} \\
334[325-357]^{\mathrm{e}}\end{array}$ & $\begin{array}{l}379[379-452] \\
357[334-375]^{\mathrm{d}} \\
366[348-392]^{\mathrm{e}}\end{array}$ & $328[328-422]$ & $377[377-450]$ \\
\hline Agriculture and waste & $\begin{array}{l}159[159-203] \\
208[187-220]^{\mathrm{b}} \\
185[172-197]^{\mathrm{c}}\end{array}$ & $\begin{array}{l}172[172-224] \\
239[180-301]^{\mathrm{b}} \\
188[177-196]^{\mathrm{c}}\end{array}$ & $\begin{array}{l}185[185-232] \\
209[180-241]^{\mathrm{b}} \\
200[187-224]^{\mathrm{c}} \\
202[173-219]^{\mathrm{d}} \\
192[178-206]^{\mathrm{e}}\end{array}$ & $\begin{array}{l}201[201-240] \\
219[175-239]^{\mathrm{d}} \\
206[191-223]^{\mathrm{e}}\end{array}$ & 181 [181-233] & 200 [200-239] \\
\hline Biomass burning & 13 [13-16] & 18 [18-24] & $\begin{array}{l}15[15-18] \\
19[15-32]^{\mathrm{e}}\end{array}$ & $\begin{array}{l}14[14-17] \\
17[14-26]^{\mathrm{e}}\end{array}$ & 15 [15-20] & 14 [14-17] \\
\hline Fossil fuels & $\begin{array}{l}104[104-132] \\
94[75-108]^{\mathrm{b}} \\
89[89-89]^{\mathrm{c}}\end{array}$ & $\begin{array}{l}107[107-139] \\
95[84-107]^{\mathrm{b}} \\
84[66-96]^{\mathrm{c}}\end{array}$ & $\begin{array}{l}127[127-159] \\
96[77-123]^{\mathrm{b}} \\
96[85-105]^{\mathrm{c}} \\
100[70-149]^{\mathrm{d}} \\
110[93-129]^{\mathrm{e}}\end{array}$ & $\begin{array}{l}151[151-180] \\
109\left[^{2}-168\right]^{\mathrm{d}} \\
127[111-154]^{\mathrm{e}}\end{array}$ & $120[120-153]$ & 150 [150-179] \\
\hline Other anthropogenic sources & 14 [14-17] & $14[14-18]$ & 13 [13-16] & 13 [13-16] & $12[12-16]$ & 13 [13-16] \\
\hline$\Delta E^{\mathrm{f}, \mathrm{g}}$ & 47 [23-79] & $60[36-94]$ & $52[29-85]$ & 39 [16-73] & 57 [34-93] & 40 [17-73] \\
\hline \multicolumn{7}{|l|}{ Sinks $\mathrm{g}$} \\
\hline Total chemical loss & $\begin{array}{l}486[462-519] \\
490[450-533]^{\mathrm{b}} \\
539[411-671]^{\mathrm{c}}\end{array}$ & $\begin{array}{l}540[516-573] \\
525[491-554]^{\mathrm{b}} \\
571[521-621]^{\mathrm{c}}\end{array}$ & $\begin{array}{l}577[553-610] \\
518[510-538]^{\mathrm{b}} \\
604[483-738]^{\mathrm{c}} \\
505[459-516]^{\mathrm{d}} \\
595[489-749]^{\mathrm{e}}\end{array}$ & $\begin{array}{l}592[569-626] \\
518[474-532]^{d}\end{array}$ & $570[546-603]$ & $592[568-625]$ \\
\hline $\mathrm{OH}$ loss & $\begin{array}{l}442[419-476] \\
468[382-567]^{\mathrm{c}}\end{array}$ & $\begin{array}{l}486[462-519] \\
479[457-501]^{c}\end{array}$ & $\begin{array}{l}526[502-559] \\
528[454-617]^{\mathrm{c}} \\
553[476-677]^{\mathrm{e}}\end{array}$ & 543 [519-576] & $519[495-552]$ & 542 [519-576] \\
\hline $\mathrm{O}\left({ }^{1} \mathrm{D}\right)$ loss & $\begin{array}{l}38 \\
46[16-67]^{c}\end{array}$ & $\begin{array}{l}47 \\
67[51-83]^{\mathrm{c}}\end{array}$ & $\begin{array}{l}43 \\
51[16-84]^{\mathrm{c}} \\
31[12-37]^{\mathrm{e}}\end{array}$ & 42 & 44 & 42 \\
\hline
\end{tabular}


Table 4. Continued.

\begin{tabular}{|c|c|c|c|c|c|c|}
\hline Period of time & 1980-1989 & 1990-1999 & 2000-2009 & 2008-2017 & 1999-2006 & 2007-2017 \\
\hline $\mathrm{Cl}$ loss & $\begin{array}{l}5 \\
25[13-37]^{\mathrm{c}}\end{array}$ & $\begin{array}{l}7 \\
25[13-37]^{\mathrm{c}}\end{array}$ & $\begin{array}{l}7 \\
25[13-37]^{\mathrm{c}} \\
11[1-35]^{\mathrm{e}}\end{array}$ & 7 & 8 & 7 \\
\hline Soils & $\begin{array}{l}13 \\
21[10-27]^{b} \\
28[9-47]^{c}\end{array}$ & $\begin{array}{l}14 \\
27[27-27]^{b} \\
28[9-47]^{c}\end{array}$ & $\begin{array}{l}14 \\
32[26-42]^{\mathrm{b}} \\
28[9-47]^{\mathrm{c}} \\
34[27-41]^{\mathrm{d}} \\
30[11-49]^{\mathrm{e}}\end{array}$ & $\begin{array}{l}14 \\
38[27-45]^{\mathrm{d}}\end{array}$ & 14 & 14 \\
\hline Totals $\mathrm{g}$ & & & & & & \\
\hline Sum of sources & $\begin{array}{l}539[515-571] \\
551[500-592]^{\mathrm{b}} \\
663[536-789]^{\mathrm{c}}\end{array}$ & $\begin{array}{l}574[549-608] \\
554[529-596]^{\mathrm{b}} \\
649[511-812]^{\mathrm{c}}\end{array}$ & $\begin{array}{l}595[572-628] \\
548[526-569]^{\mathrm{b}} \\
678[542-852]^{\mathrm{c}} \\
572[538-593]^{\mathrm{d}} \\
737[593-880]^{\mathrm{e}}\end{array}$ & $\begin{array}{l}621[598-655] \\
545[522-559]^{\mathrm{d}} \\
703[570-842]^{\mathrm{e}}\end{array}$ & 589 [565-625] & 620 [597-653] \\
\hline Sum of sinks & $\begin{array}{l}499[475-532] \\
511[460-559]^{\mathrm{b}} \\
539[420-718]^{\mathrm{c}}\end{array}$ & $\begin{array}{l}554[530-586] \\
542[518-579]^{\mathrm{b}} \\
596[530-668]^{\mathrm{c}}\end{array}$ & $\begin{array}{l}591[567-624] \\
540[514-560]^{\mathrm{b}} \\
632[592-785]^{\mathrm{c}} \\
540[486-556]^{\mathrm{d}} \\
625[600-798]^{\mathrm{e}}\end{array}$ & $\begin{array}{l}606[583-640] \\
556[501-574]^{d}\end{array}$ & 584 [560-617] & 606 [582-639] \\
\hline Imbalance & $\begin{array}{l}40[39-40] \\
30[16-40]^{\mathrm{b}}\end{array}$ & $\begin{array}{l}20[19-22] \\
12[7-17]^{b}\end{array}$ & $\begin{array}{l}4[4-5] \\
4[-11-36]^{\mathrm{d}} \\
8[-4-19]^{\mathrm{b}}\end{array}$ & $\begin{array}{l}15[15-15] \\
16\left[^{[0-47]^{\mathrm{d}}}\right.\end{array}$ & $5[5-8]$ & 14 [15-14] \\
\hline Atmospheric growth & $\begin{array}{l}36 \\
34^{\mathrm{b}} \\
32^{\mathrm{h}}\end{array}$ & $\begin{array}{l}19 \\
17^{\mathrm{b}, \mathrm{h}}\end{array}$ & $\begin{array}{l}4.8 \\
6^{\mathrm{b}, \mathrm{h}}\end{array}$ & $\begin{array}{l}16.7 \\
18.7 \pm 2.7^{\mathrm{h}}\end{array}$ & $\begin{array}{l}3.5 \\
1.9 \pm 1.6^{\mathrm{h}}\end{array}$ & $\begin{array}{l}16.6-17.2 \\
18.9 \pm 1.7^{h}\end{array}$ \\
\hline
\end{tabular}

a The decadal mean values are based on initial emission inventories. The lower and upper limits of the ranges are based on the minimum and maximum among all the optimized emission scenarios (i.e., S0Aopt, S0Wopt, S1Aopt, S1Wopt, S2Aopt, and S2Wopt) conducted in this work.

b Values are based on the Kirschke et al. (2013) top-down approach.

c Values are based on the Kirschke et al. (2013) bottom-up approach.

d Values are based on the Saunois et al. (2020) top-down approach.

e Values are based on the Saunois et al. (2020) bottom-up approach.

f $\Delta E$ is calculated based on the methodology of Ghosh et al. (2015).

$\mathrm{g}$ The ranges are based on the low-OH (S1Wopt) and high-OH cases (S2Wopt), and the decadal mean values shown in the table are based on the default OH (SOWopt).

$\mathrm{h}$ The observed atmospheric growth rates $\left(\mathrm{Tg} \mathrm{yr}^{-1}\right.$ ) are estimated based on a few MBL sites (Dlugokencky et al., 2018), which are not the same as the Imbalance Row (based on the entire globe).

Table 4 provides a summary of the decadal mean methane budget for 1980-2017. Compared to Kirschke et al. (2013) and Saunois et al. (2020), total natural emissions from the initial emission inventories $\left(203 \mathrm{Tg} \mathrm{yr}^{-1}\right)$ are at the lower range of top-down estimates during this period, except for the 1990s, when they are slightly greater than top-down estimates but still much lower than the bottom-up estimates. Since there is no observational constraint on bottom-up estimates, total natural emissions are simply summed over independent individual sources, which could be overestimated in the bottom-up approach considering the relatively large uncertainties in each individual source. In addition, in the bottom-up estimate from Kirschke et al. (2013) and Saunois et al. (2016), some other natural sources, such as freshwater, are not included in the initial emission inventories in this work; however, they are likely double counted in the bottom-up estimates (e.g., high-latitude inland waters are likely also considered as wetland areas) as pointed out in Saunois et al. (2020). The natural emissions estimated in this work (e.g., 203-297 $\mathrm{Tg} \mathrm{yr}^{-1}$ ) are much more comparable to previous top-down estimates (e.g., $150-273 \mathrm{Tg} \mathrm{yr}^{-1}$ as shown in Kirschke et al., 2013), which demonstrates confidence in the natural source estimates. Total anthropogenic emissions from the initial emission inventories are overall within the range of top-down or bottom-up estimates, except for 1980-1989, when they are less than the estimates in Kirschke et al. (2013). The low values in the 1980s result mainly from low estimated emissions from agriculture and waste sectors in the CEDS inventory. With the optimized global total emissions, the total sources used in this work and the total sinks estimated by AM4.1 are in the range of either top-down or bottom-up estimates by previous studies. As a 


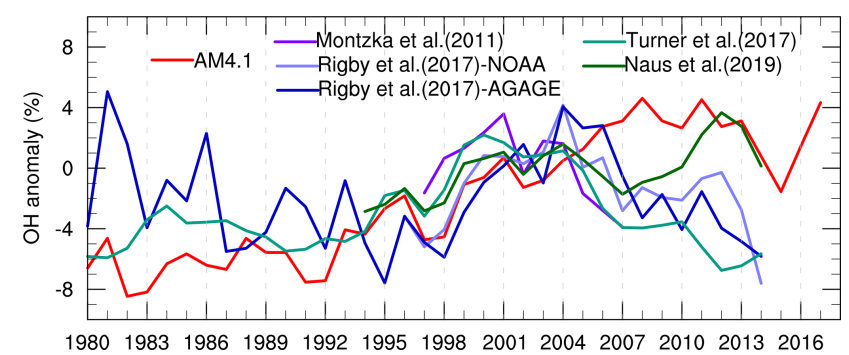

Figure 6. Time series of global tropospheric $\mathrm{OH}$ anomalies with respect to 1998-2007. Results of Montzka et al. (2011) are shown in dark purple (with the mean interannual variability of $\mathrm{OH}$ as $\pm 2.3 \%$ for the period of 1998-2007). Results of Rigby et al. (2017) derived from NOAA observations are shown in light blue (with the mean interannual variability of $\mathrm{OH}$ as $\pm 2.3 \%$ for the period of $1998-2007$ and $\pm 2.6 \%$ for the period of 1980-2014), and those derived from AGAGE observations are shown in dark blue (with the mean interannual variability of $\mathrm{OH}$ as $\pm 3.0 \%$ for the period of 1998-2007 and $\pm 3.1 \%$ for the period of 1980-2014). Results from Turner et al. (2017) are shown in green (with the mean interannual variability of $\mathrm{OH}$ as $\pm 2.0 \%$ for the period of $1998-2007$ and $\pm 2.5 \%$ for the period of 1980-2014). Results from Naus et al. (2019) are shown in dark green (with the mean interannual variability of $\mathrm{OH}$ as $\pm 1.2 \%$ for the period of $1998-2007$ and $\pm 1.8 \%$ for the period of 1994 2014). OH anomalies in this work are shown in red (with the mean interannual variability of $\mathrm{OH}$ as $\pm 2.2 \%$ for the period of 1998 2007 and $\pm 4.1 \%$ for the period of $1980-2014$ ).

result, the imbalance between total emissions and total sinks estimated in this work is, overall, within the range of estimates by previous studies, although we find a smaller imbalance than previous estimates for the 2000s and afterwards. The atmospheric growth rates simulated by the model (sampled identically as for observations) are also comparable to the observed atmospheric growth rates.

\subsection{Source-tagged tracers}

In this section, we apply the Mann-Kendall (M-K) test to estimate the linear trend of global mean source-tagged tracers and total methane for 1983-1998, 1999-2006, and 2007-2017 to investigate possible drivers of total methane trends. Figure 7 compares the trends of source-tagged tracers and total methane from S0Aopt and SoWopt during each time period. For S0Aopt, total methane increases strongly at $10.5 \mathrm{ppbyr}^{-1}$ during 1983-1998. The tagged anthropogenic tracers all show increasing trends during 1983-1998 despite the increases in $\mathrm{OH}$ levels, with dominant increasing trends by CH4AGR and CH4WST consistent with emission trends. Since wetland emissions and other natural emissions are kept constant every year in S0Aopt, with increases in $\mathrm{OH}$ levels during 1983-1998, all tagged natural tracers show a weak decreasing trend. During 1999-2006, total methane shows a small increasing trend of $1.0 \mathrm{ppb} \mathrm{yr}^{-1}$, due to the increasing trends of CH4ENE and CH4WST compensated by the decreasing trends of other source-tagged tracers. The increas- ing trends of CH4ENE and CH4WST are mainly driven by the increases in the emissions from energy and waste sectors in S0Aopt, whereas the decreasing trends of other source-tagged tracers are mainly driven by the increases in $\mathrm{OH}$ levels. Compared to the rapid growth during 19831998, only CH4ENE growth rate shows a small increase during 1999-2006 (2.6 vs. $2.2 \mathrm{ppbyr}^{-1}$ in 1983-1998), with all other tracers showing a decrease in their growth rates. Despite higher anthropogenic emissions during 1999-2006 than previous periods, the sinks are also higher, leading to a relative stabilization. During 2007-2017, total methane shows a renewed increasing trend of $5.3 \mathrm{ppbyr}^{-1}$, dominated by a strong increasing trend of CH4ENE $\left(5.9 \mathrm{ppb} \mathrm{yr}^{-1}\right)$ and smaller increasing trends of CH4AGR and CH4WST. Compared to 1999-2006, there is a significant increase in CH4ENE growth rate with smaller increases in CH4AGR growth rate during 2007-2017. Although the CH4WST growth rate decreased in 2007-2017, the continued increasing trend of CH4WST together with those of CH4AGR and $\mathrm{CH} 4 \mathrm{ENE}$ contribute to the renewed growth in methane. The results from S0Aopt suggest that globally anthropogenic tracers dominate total methane trends during the entire simulation period. During the 1980s and 1990s, emissions from agriculture, energy, and waste sectors are the major contributors to the methane increase. During 1999-2006, when atmospheric methane stabilizes, increases in methane sinks and methane sources alternatively dominate the trend for different tracers. Compared to 1999-2006, higher emissions from agriculture, energy, and waste sectors during 2007-2017 are the major drivers for the renewed growth in methane, with the energy sector as the largest contributor.

The source-tagged tracers behave slightly differently in SoWopt. For S0Wopt, total methane shows an increasing trend similar to that of S0Aopt. During 1983-1998, the tagged anthropogenic tracers all show increasing trends except CH4ENE, with overall smaller increasing trends than those in SOAopt. CH4WET shows a strong increasing trend $\left(7.0 \mathrm{ppbyr}^{-1}\right)$, dominating the total methane trend. This is mainly because wetland emission growth is larger than anthropogenic emission growth due to the emission optimization in SOWopt during this period. During 1999-2006, similar to SOAopt, the total methane trend results from the increasing trends of $\mathrm{CH} 4 \mathrm{ENE}$ and $\mathrm{CH} 4 \mathrm{WST}$ compensated by the decreasing trends of other source-tagged tracers. During this time, CH4WET shows a slightly decreasing trend $\left(-0.8 \mathrm{ppbyr}^{-1}\right)$, reflecting the slightly greater CH4WET sinks $\left(226 \mathrm{Tg} \mathrm{yr}^{-1}\right)$ than emissions $\left(223 \mathrm{Tg} \mathrm{yr}^{-1}\right)$. Similar to S0Aopt, only CH4ENE shows an increase in its growth rate during this time period compared to previous time periods. During 2007-2017, the total methane trend is dominated by the increasing trends of CH4AGR, CH4ENE, and CH4WST, with CH4ENE as the largest contributor, similar to S0Aopt. On the other hand, CH4WET shows a significant decreasing trend during this period, with CH4WET sinks $\left(217 \mathrm{Tg} \mathrm{yr}^{-1}\right)$ larger than emissions $\left(206 \mathrm{Tg} \mathrm{yr}^{-1}\right)$. Compared to 1999 

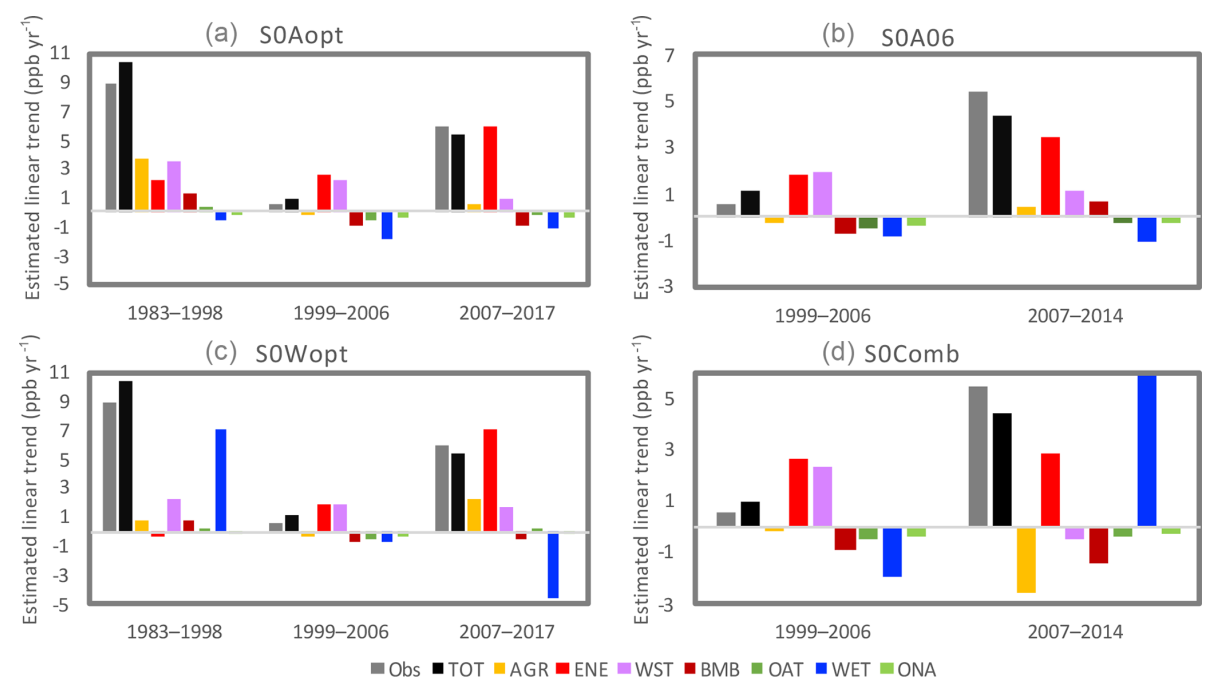

Figure 7. Estimated global linear trends for source-tagged tracers and total methane (TOT). The source-tagged tracers include tracers for the agriculture sector (AGR), energy sector, (ENE), waste sector (WST), biomass burning sector (BMB), other anthropogenic sectors (OAT), wetland sector (WET), and other natural sectors (ONA). The grey bar represents the total methane trend from NOAA GMD observations. In panels (a) and (c) (i.e., S0Aopt and S0Wopt), the trends are estimated for the periods of 1983-1998, 1999-2006, and 2007-2017. In panels (b) and (d) (i.e., S0A06 and S0Comb), the trends are estimated for the period of 2007-2014, with 1999-2006 trends from S0Wopt and SOAopt.

2006, there is a significant increase in CH4ENE growth rate with a noticeable increase in CH4AGR growth rate during 2007-2017. Although the CH4WST growth rate also decreased in 2007-2017, similar to S0Aopt, the continued increasing trend of CH4WST together with those of CH4AGR and CH4ENE contribute to the renewed growth in methane. On the other hand, CH4WET shows a significant decrease in its growth rate during this time period compared to 19992006, mainly due to lower emissions (206 $\mathrm{Tg} \mathrm{yr}^{-1}$ in $2007-$ 2017 vs. $223 \mathrm{Tg} \mathrm{yr}^{-1}$ in 1999-2006) imposed in this scenario. Compared to the S0Aopt results, SOWopt suggests CH4WET as the largest contributor for the methane trends during the 1980s and 1990s, mainly due to emission optimization of different sectors. However, both scenarios suggest CH4AGR, CH4WST, and CH4ENE are the major contributors to the renewed growth in methane, with CH4ENE as the largest contributor.

As shown in Figs. 5 and 6, OH levels slightly decrease and methane sinks are relatively stable during 2007-2013, but large interannual variability exists during 2013-2017. Decreasing $\mathrm{OH}$ levels could lead to increases in methane lifetime and therefore methane buildup. Combined with increases in the emissions, methane starts to increase again during this period. However, it is difficult to separate the contributions from methane emissions and sinks as optimized methane emissions are based on methane mass balance (e.g., changes in methane loss would act as a feedback on estimates of optimized total emissions). Nevertheless, it is clear that the decrease in $\mathrm{OH}$ levels alone (e.g., if emissions are kept constant) would not be enough to reproduce the renewed growth. The remaining question is then as follows: which emission sectors are the major contributors to the renewed growth from 2007 to 2017? Both S0Wopt and S0Aopt suggest that the agriculture, waste, and energy sectors are the major contributors to renewed methane growth. However, both cases depend largely on the initial emission inventory and the scaling methods chosen. For example, SOWopt relies on the emission growth of other sectors from the initial emission inventory, which means if the emission growth of a certain sector is overestimated or underestimated in the initial emission inventory, it would lead to different results. Therefore, we conducted two additional sensitivity simulations (i.e., S0A06 and S0Comb as described in Sect. 2.3) with different emission growths for anthropogenic and wetland sectors as in S0Aopt and S0Wopt for 2006-2014.

The trends for source-tagged tracers and total methane by S0A06 and S0Comb are shown in Fig. 7. Interestingly, in S0A06, where anthropogenic and biomass burning emissions are kept constant every year for 2006-2014, anthropogenic tracers, particularly CH4ENE and CH4WST, still show increasing trends during 2007-2014, whereas CH4WET shows a small decreasing trend despite rising emissions. As OH levels slightly decrease during this time (but are still higher than 1999-2006), with constant emissions except for wetland, one might expect possible increasing trends in all tagged tracers except CH4WET. In fact, major anthropogenic tracers such as CH4AGR, CH4ENE, CH4WST, and CH4BMB increase over 2007-2014 in S0A06, but at a slower rate than in SOWopt (and S0Aopt) due to no emission growth for these tracers. On the other hand, the decreasing $\mathrm{OH}$ levels 


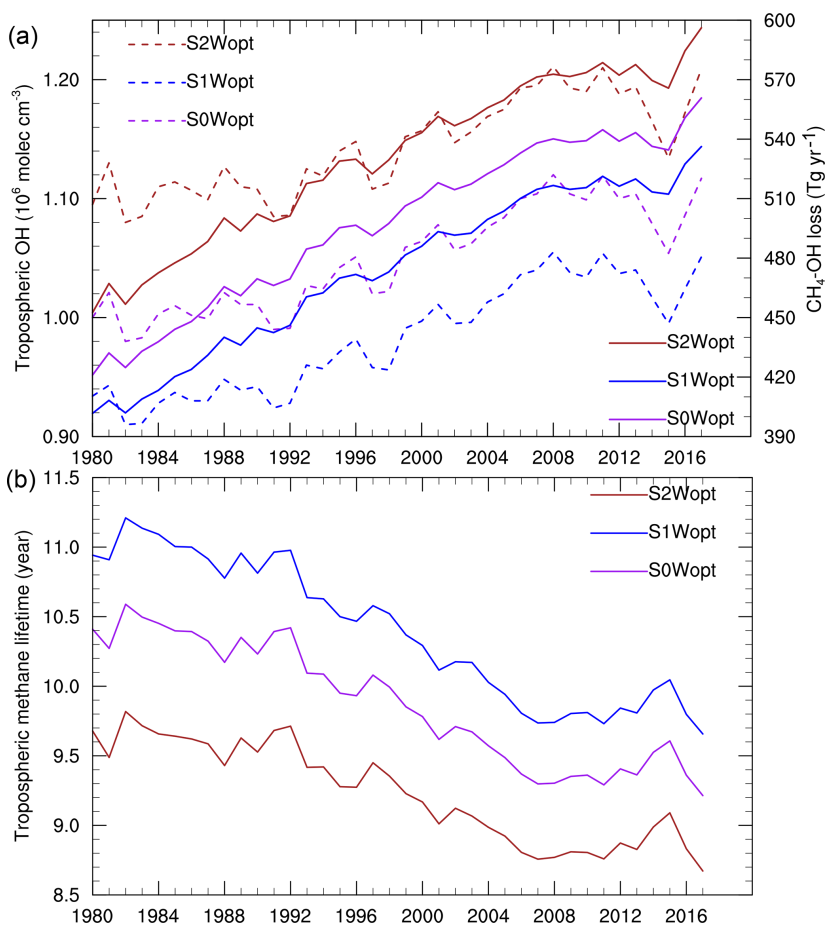

Figure 8. Time series of global tropospheric $\mathrm{OH}$ levels (left $y$ axis, dashed line) and methane $\mathrm{OH}$ loss (right $y$ axis, solid line) from SoWopt (purple), S1Wopt (blue), and S2Wopt (brown) in panel (a) and time series of methane tropospheric lifetime from SoWopt (purple), S1Wopt (blue), and S2Wopt (brown) in panel (b).

(Fig. 6) would lead to a smaller methane sink and therefore higher methane concentrations. Since methane loss is proportional to the product of $\mathrm{OH}$ levels and methane concentrations, and concentrations of CH4WET are much greater than other source-tagged tracers, the loss of CH4WET is also much greater than other tracers. Higher CH4WET loss $\left(223 \mathrm{Tg} \mathrm{yr}^{-1}\right)$ than CH4WET emissions $\left(222 \mathrm{Tg} \mathrm{yr}^{-1}\right)$ leads to a slightly decreasing trend in CH4WET. In other words, despite the increasing source contributions from wetlands to total methane emissions, the relative contributions of wetland tracer to total methane abundance are declining. Compared to 1999-2006, there are major increases in the growth rates of CH4ENE and CH4BMB, with a smaller increase in CH4AGR and CH4OAT growth rates, which drives the renewed methane growth. Meanwhile, CH4WET is still declining during 2007-2014 $\left(-1.1 \mathrm{ppbyr}^{-1}\right)$, but at a larger decrease rate than for $1999-2006\left(-0.8 \mathrm{ppbyr}^{-1}\right)$. Nevertheless, S0A06 results suggest that the renewed growth during 2007-2014 is contributed by the increased growth rates of CH4ENE, CH4BMB, and CH4AGR as well as increasing trend of CH4WST, mainly due to higher anthropogenic emissions than 1999-2006 and decreases in OH levels during 2008-2014. The results also suggest $\mathrm{OH}$ trends play an important role in determining the increasing trend of total methane since emissions of the energy and waste sectors are kept constant in this sensitivity simulation. In addition, increases in wetland emissions alone are not able to drive increases in CH4WET over this period, as CH4WET sinks are equally important for determining the trend in CH4WET. Our analysis also suggests that increased emissions from other microbial sources (e.g., agriculture and waste) are needed to match the observed negative trend in $\delta^{13} \mathrm{CH}_{4}$ since 2007 (Nisbet et al., 2019).

The trends for source-tagged tracers and total methane behave differently in S0Comb, where we combine S0Aopt emissions for 1980-2005 and S0Wopt emissions for 20062014. During 2007-2014, all anthropogenic tracers show decreasing trends except CH4ENE (2.8 $\mathrm{ppbyr}^{-1}$ ), whereas CH4WET shows a significant increasing trend $\left(5.9 \mathrm{ppb} \mathrm{yr}^{-1}\right)$ and dominates the total methane trend. This is mainly due to lower anthropogenic emissions during this period than previous periods, allowing sinks of anthropogenic methane tracers to start to take over their trends except for CH4ENE. At the same time, significantly higher wetland emissions during this period than previous periods dominate the increasing trend of CH4WET. Interestingly, even with the same wetland emissions in S0Wopt and S0Comb for 2006-2014, CH4WET shows different trends. This is mainly because the CH4WET concentrations at the beginning of 2006 are much lower in SOComb than in SOWopt. Therefore, CH4WET loss is much lower in S0Comb $\left(190 \mathrm{Tg} \mathrm{yr}^{-1}\right)$ compared to SoWopt $\left(220 \mathrm{Tg} \mathrm{yr}^{-1}\right)$ over this time, leading to an increasing CH4WET trend in SOComb, but a decreasing trend in S0Wopt. Compared to 1999-2006, there is a significant increase in CH4WET growth rate with a minor increase in CH4ENE growth rates during 2007-2014, which drives the renewed growth in methane. SOComb results suggest the need for a sharp increase in wetland emissions with a concomitant sharp decrease in anthropogenic emissions in 2006 to drive the methane growth by wetland tracer. It is a likely scenario for a sharp increase in wetland emissions considering the interannual variability. However, it is a less likely scenario for a concomitant sharp decrease in anthropogenic emissions as both top-down and bottom-up inventories indicate anthropogenic emissions increasing over the 2000s. A more likely scenario is that both anthropogenic and wetland emissions increase (i.e., higher during 2007-2014 than 1999-2006). However, in that case, the dominance of wetland emissions in driving the total methane trend would decrease based on our analysis.

\subsection{Sensitivity to $\mathrm{OH}$ levels}

As described in Sect. 2.3, we perform two additional simulations for low and high OH levels (i.e., S1 and S2) for 19802017 to investigate the sensitivity of methane predictions to different $\mathrm{OH}$ levels. For both $\mathrm{OH}$ cases, the interannual variations in $\mathrm{OH}$ levels are the same as in S0 because the simulations are driven by the same meteorology. Figure 8a and b show global tropospheric $\mathrm{OH}$ concentrations, $\mathrm{OH}$-driven 
methane loss, and tropospheric methane lifetime for the three cases (i.e., S0, S1, and S2) in which wetland emissions are optimized (Wopt; Aopt has a very similar global $\mathrm{OH}$ trend to Wopt). Compared to $\mathrm{S} 0$, scaling $\mathrm{LNO}_{x}$ production in the model by a factor of 0.5 leads to a reduction in simulated annual global mean $\mathrm{OH}$ levels by $-6.4 \%$ and an increase in methane lifetime by 0.5 years in S1 over 1980-2017; scaling by a factor of 2 leads to an increase in simulated annual global mean $\mathrm{OH}$ by $+9.1 \%$ and a decrease in methane lifetime by 0.7 years in $\mathrm{S} 2$. The global mean $\mathrm{OH}$ levels increase from 1980 to 2008 (by $3.6 \%$, with respect to the 1980 level), decrease from 2008 to 2015 (by $2.3 \%$, with respect to the 2008 level), and increase from 2015 to 2017 (by 4.6\%, with respect to the 2015 level). However, compared to the 19982007 average, $\mathrm{OH}$ levels during 2008-2015 and 2015-2017 are still greater by $2.5 \%$ and $1.3 \%$, respectively. Changes in $\mathrm{OH}$ levels depend on a number of factors (e.g., temperature, water vapor, $\mathrm{O}_{3}, \mathrm{NO}_{x}, \mathrm{CO}$, and VOCs). Therefore, $\mathrm{OH}$ is influenced by the specific chemistry and forcing data used in the model. Nevertheless, our estimates in $\mathrm{OH}$ trends and variabilities from all three cases are quite comparable to the those estimated by the Chemistry Climate Model Initiative (CCMI) models (e.g., Zhao et al., 2019). Since emission optimization is also based on methane sinks, the total optimized emissions in $\mathrm{S} 1$ are lower than those in S0 by about $4.1 \%$ (with an annual mean of $-24 \mathrm{Tg} \mathrm{yr}^{-1}$ ), and the total optimized emissions in S2 are higher than those in S0 by about $5.8 \%$ (or $33 \mathrm{Tg} \mathrm{yr}^{-1}$ ). This indicates that a $1 \%$ change in $\mathrm{OH}$ levels could lead to about $4 \mathrm{Tg} \mathrm{yr}^{-1}$ difference in the optimized emissions. Increasing methane loss due to $\mathrm{OH}$ is simulated for 1980-2007 in the three cases due to increases in $\mathrm{OH}$ and methane concentrations (except over the stabilization period when methane was not increasing but $\mathrm{OH}$ was increasing). During 2007-2013, the simulated decrease in OH levels combined with increasing methane concentrations leads to relative stabilization in $\mathrm{OH}$-driven methane loss in the three cases. The large interannual variability in $\mathrm{OH}$ levels during 2013-2017 dominates the interannual variability in methane $\mathrm{OH}$ loss despite the continued increases in methane.

All three simulations show a similar trend for tropospheric methane lifetime, with a decreasing trend from 1980 to $2007\left(-0.04 \mathrm{yryr}^{-1}\right.$ in S0, $-0.05 \mathrm{yryr}^{-1}$ in S1, and $-0.03 \mathrm{yryr}^{-1}$ in S2), a clear increasing trend during 20112015 (0.08 $\mathrm{yryr}^{-1}$ in all three simulations), and a decreasing trend during 2015-2017 ( $-0.2 \mathrm{yryr}^{-1}$ in all three simulations). The mean tropospheric methane lifetime due to OH loss for 1980-2017 is 9.9 \pm 0.4 years in S0Wopt, which is about 0.5 years lower than S1Wopt $(10.4 \pm 0.5$ years) and about 0.7 years higher than S2Wopt (9.2 \pm 0.3 years), due to different $\mathrm{OH}$ levels and therefore methane sinks, but with similar methane burdens. This indicates that a $1 \%$ change in $\mathrm{OH}$ levels could lead to about a 0.08 -year difference in the tropospheric methane lifetime. The mean tropospheric methane lifetime simulated by the three simulations is within the uncertainty range of model estimates of
9.3 $\pm 0.9-9.8 \pm 1.6$ years (Voulgarakis et al., 2013; Naik et al., 2013b) and in general comparable to the observation-derived estimates of $9.1 \pm 0.9$ years for the present day (Prather et al., 2012), with a slightly higher estimate by S1Wopt. All simulations show an increase in methane lifetime during 20112015, which could be a signal of the methane feedback on its lifetime (Holmes, 2018) in the model. Continued increases in methane emissions (Fig. 5) during this time, along with decreases in tropospheric $\mathrm{OH}$ concentrations (Fig. 8), lengthen the lifetime of methane and therefore amplify methane's response to emission changes. If methane emissions continue to increase, we can expect stronger increases in atmospheric methane due to the amplifying effect of the methane-OH feedback as occurred in the significant increases in methane growth rates during 2014 and 2015.

\section{Conclusions}

In this work, we thoroughly evaluate the atmospheric methane budget simulated by the GFDL atmospheric chemistry model AM4.1 and apply the model to attribute the drivers of changes in global methane over the past 4 decades. We simulate methane and related tracers for 1980-2017 by driving the model with gridded emissions compiled from various sources. To match the long-term record of surface methane measurements, we optimize global total methane emissions using a simple mass balance approach. Our optimized global total methane emissions are within the range of estimates by previous studies (both bottom-up and topdown). The GFDL-AM4.1 simulations with emissions following two different optimizations (anthropogenic sources and wetlands) both reproduce observed global methane trends and variabilities, despite the different contributions from anthropogenic and wetland emissions. This, therefore, suggests that accurate estimates of global total emissions and of their interannual variability are critical in predicting the global methane trend and its variability, despite uncertainties in the estimates of individual sources. In addition, both simulations are in general able to capture the spatial distribution and seasonal cycle of methane as observed by NOAA GMD sites and vertical distribution of methane as measured from aircraft, demonstrating the reasonable spatial and temporal representations of the optimized emissions derived in this work.

We then explore the contributions of changes in methane sources and sinks to methane trends and variability over 1980-2017. The simulation with optimization of anthropogenic emissions shows increasing anthropogenic emissions to drive the rapid methane growth during the 1980s and 1990s, whereas the simulation with optimization of wetland emissions also shows wetland to be one of the major contributors during these periods. However, both simulations suggest increases in methane sources (mainly from agriculture, energy, and waste sectors), balanced by the increases in 
methane sinks (mainly due to increases in $\mathrm{OH}$ levels), lead to methane stabilization during 1999-2006 and that the agriculture, energy, and waste sectors are the major contributors to the renewed growth in methane after 2006.

Two additional sensitivity simulations further investigate the contributions of wetlands to the renewed methane growth during 2007-2014. The simulation with repeating 2006 emissions for all the sectors except wetland shows a declining contribution of wetland tracer to total methane abundance despite the increasing contribution of wetland emissions to total emissions, because sinks are equally important for determining the tracer trend. Results from a simulation with combined optimizations (i.e., 1980-2005 optimized anthropogenic emissions and 2006-2014 optimized wetland emissions) suggest that a sharp increase in wetland emissions (a likely scenario) with a concomitant sharp decrease in anthropogenic emissions (a less likely scenario) would be required starting in 2006 to drive the methane growth by the wetland tracer.

Two additional sensitivity simulations, with low and high $\mathrm{OH}$ levels (by scaling $\mathrm{LNO}_{x}$ production in the model by a factor of 0.5 and 2), further investigate methane $\mathrm{OH}$ loss and tropospheric methane lifetime. In general, $\mathrm{OH}$ trends dominate methane $\mathrm{OH}$ loss trends during different methane growth periods except 2007-2013, when methane OH loss shows little change due to the decrease in $\mathrm{OH}$ levels combined with the increase in methane concentrations. The results also indicate that a $1 \%$ change in $\mathrm{OH}$ levels could lead to about a $4 \mathrm{Tgyr}^{-1}$ difference in the optimized emissions and a 0.08 -year difference in the estimated tropospheric methane lifetime. The increasing methane lifetime during 2011-2015 in all the $\mathrm{OH}$ sensitivity simulations indicates a possible methane feedback on its lifetime in the model. Continued increases in methane emissions along with decreases in tropospheric $\mathrm{OH}$ concentrations extend the lifetime of methane and therefore amplify methane's response to emission changes.

Essentially, the global atmospheric methane trend is driven by the competition between its emissions and sinks. Our model results suggest that the methane stabilization during 1999-2006 is mainly due to increasing emissions balanced by increasing sinks, whereas the renewed methane growth during 2007-2013 is mainly due to increasing sources combined with little change in sinks despite small decreases in $\mathrm{OH}$ levels. The significant increases in methane growth during 2014-2015 are mainly due to increasing sources combined with decreasing sinks. Most of the model simulations conducted here suggest that increases in energy sources drive the renewed methane growth, in agreement with previous studies (e.g., Rice et al., 2016; Hausmann et al., 2016; Worden et al., 2017), with the second largest contributor from the waste sector and third largest contributor from the agriculture sector, consistent with the shift in the isotopic ratio ${ }^{13} \mathrm{CH}_{4}$. However, optimization of emissions from anthropogenic sources depends on the "shares" of individual an- thropogenic sectors in the initial emission inventories. Uncertainties in these shares could lead to uncertainties in the emission adjustment for each anthropogenic sector. Recent studies using methane isotopic composition suggest that renewed growth in methane since 2007 is more likely due to the increases in biogenic sources (e.g., Schaefer et al., 2016) as $\delta^{13} \mathrm{CH}_{4}$ is shifting to more negative values after increasing during the 1980s and 1990s and remaining relatively stable during 1999-2006. However, this shift could also imply increases in isotopically lighter fossil fuel emissions, decreases in isotopically heavy sources (e.g., biomass burning), or increases in both microbial and fossil fuel emissions but with increases in microbial emissions stronger than those from fossil fuel sources (Nisbet et al., 2019). It is quite possible that, rather than the energy sector, the increases in the agriculture and waste sectors could be the largest contributors to the renewed growth in methane. In that case, it is possible that the growth of agriculture and waste emissions could be underestimated in the optimized emissions, while the growth of energy emissions could be overestimated.

The optimized emission totals estimated in this work represent temporal and spatial distribution of total methane sources reasonably well. However, the emission adjustments are either applied to anthropogenic (including biomass burning) sectors only (uniformly to all anthropogenic sectors) or to the wetland sector only. Uncertainties therefore exist on the distribution of the emission adjustments to individual sectors. Without accurate estimates of emissions from individual sources, it would be difficult to attribute the methane trend and variability to specific sectors. The application of methane isotopes and additional observational constraints (e.g., ethane and $\delta^{13} \mathrm{CH}_{4}$ ) could potentially help better partition the emission adjustments to different sectors. In addition, the spatial distribution of optimized emissions depends on the spatial information in the initial emission inventories. Uncertainties in the spatial distribution from the initial emission inventories may remain in the optimized emissions. Our model evaluation suggests that the optimized inventory may overestimate tropical emissions. A process-based emission model (e.g., wetland emissions) coupled with AM4.1 may better represent the spatial and temporal patterns of the emissions than prescribed in the present work.

Data availability. The GFDL-AM4.1 model simulation output is available at ftp://data1.gfdl.noaa.gov/users/Jian.He/Methane_ budget/GFDL-AM4.1/ (last access: October 2019).

Supplement. The supplement related to this article is available online at: https://doi.org/10.5194/acp-20-805-2020-supplement.

Author contributions. JH and VN designed the research. JH developed the model configuration, performed model simulations, an- 
alyzed model results, and prepared the manuscript with contributions from all co-authors. VN provided GFDL-model-ready CMIP6 emissions. LWH led the development of the base configuration of AM4.1 and provided meteorological data for nudging. ED provided surface observations. KT provided scripts to process observational data. All authors contributed to the discussion of results.

Competing interests. The authors declare that they have no conflict of interest.

Acknowledgements. This work is supported by the Carbon Mitigation Initiative at Princeton University. Atmospheric methane dry air mole fractions are obtained from the NOAA ESRL Carbon Cycle Cooperative Global Air Sampling Network (Dlugokencky et al., 2018, ftp://aftp.cmdl.noaa.gov/data/trace_gases/ch4/ flask/surface/, last access: August 2018). The globally averaged marine surface monthly mean data and annual mean growth rates are obtained from http://www.esrl.noaa.gov/gmd/ccgg/trends_ch4/ (last access: August 2018). HIPPO data are obtained from Wofsy et al. (2012) as Merged 10-second Meteorology, Atmospheric Chemistry, Aerosol Data (R_20121129). We are grateful to Prabir Patra for providing methane emissions for nearshore exchange and mud volcanoes. We also thank Fabien Paulot for processing sea surface temperatures and sea ice data and the GFDL model development team for developing the AM4.1.

Financial support. This research has been supported by the Carbon Mitigation Initiative at Princeton University (grant no. 02085(7)).

Review statement. This paper was edited by Tim Butler and reviewed by two anonymous referees.

\section{References}

Bândă, N., Krol, M., van Weele, M., van Noije, T., Le Sager, P., and Röckmann, T.: Can we explain the observed methane variability after the Mount Pinatubo eruption?, Atmos. Chem. Phys., 16, 195-214, https://doi.org/10.5194/acp-16-195-2016, 2016.

Bloom, A. A., Bowman, K. W., Lee, M., Turner, A. J., Schroeder, R., Worden, J. R., Weidner, R., McDonald, K. C., and Jacob, D. J.: A global wetland methane emissions and uncertainty dataset for atmospheric chemical transport models (WetCHARTs version 1.0), Geosci. Model Dev., 10, 2141-2156, https://doi.org/10.5194/gmd-10-2141-2017, 2017.

Bousquet, P., Ciais, P., Miller, J. B., Dlugokencky, E. J., Hauglustaine, D. A., Prigent, C., van der Werf, G. R., Peylin, P., Brunke, E.-G., Carouge, C., Langenfelds, R. L., Lathiere, J., Papa, F., Ramonet, M., Schmidt, M., Steele, L. P., Tyler, S. C., and White, J.: Contribution of anthropogenic and natural sources to atmospheric methane variability, Nature, 443, 439443, https://doi.org/10.1038/nature05132, 2006.

Bousquet, P., Ringeval, B., Pison, I., Dlugokencky, E. J., Brunke, E.G., Carouge, C., Chevallier, F., Fortems-Cheiney, A., Franken- berg, C., Hauglustaine, D. A., Krummel, P. B., Langenfelds, R. L., Ramonet, M., Schmidt, M., Steele, L. P., Szopa, S., Yver, C., Viovy, N., and Ciais, P.: Source attribution of the changes in atmospheric methane for 2006-2008, Atmos. Chem. Phys., 11, 3689-3700, https://doi.org/10.5194/acp-11-3689-2011, 2011.

Brasseur, G. P., Hauglustaine, D. A., Walters, S., Rasch, P. J., Muller, J. F., Granier, C., and Tie, X. X.: MOZART, a global chemical transport model for ozone and related chemical tracers, 1. Model description, J. Geophys. Res.-Atmos., 103, 2826528289, 1998.

Dalsøren, S. B., Myhre, C. L., Myhre, G., Gomez-Pelaez, A. J., Søvde, O. A., Isaksen, I. S. A., Weiss, R. F., and Harth, C. M.: Atmospheric methane evolution the last 40 years, Atmos. Chem. Phys., 16, 3099-3126, https://doi.org/10.5194/acp16-3099-2016, 2016.

Dentener, F., Kinne, S., Bond, T., Boucher, O., Cofala, J., Generoso, S., Ginoux, P., Gong, S., Hoelzemann, J. J., Ito, A., Marelli, L., Penner, J. E., Putaud, J.-P., Textor, C., Schulz, M., van der Werf, G. R., and Wilson, J.: Emissions of primary aerosol and precursor gases in the years 2000 and 1750 prescribed data-sets for AeroCom, Atmos. Chem. Phys., 6, 43214344, https://doi.org/10.5194/acp-6-4321-2006, 2006.

Dlugokencky, E. J., Dutton, E. G., Novelli, P. C., and Masarie, K. A.: Changes in $\mathrm{CH}_{4}$ and $\mathrm{CO}$ growth rates after the eruption of Mt. Pinatubo and their link with changes in tropical tropospheric UV flux, Geophys. Res. Lett., 23, 2761-2764, 1996.

Dlugokencky, E. J., Houweling, S., Bruhwiler, L., Masarie, K., Lang, P., Miller, J., and Tans, P.: Atmospheric methane levels off: Temporary pause or a new steady-state?, Geophys. Res. Lett., 30, 19, https://doi.org/10.1029/2003GL018126, 2003.

Dlugokencky, E. J., Myers, R., Lang, P., Masarie, K., Crotwell, A., Thoning, K., Hall, B., Elkins, J., and Steele, L.: Conversion of NOAA atmospheric dry air $\mathrm{CH}_{4}$ mole fractions to a gravimetrically prepared standard scale, J. Geophys. Res., 110, D18306, https://doi.org/10.1029/2005JD006035, 2005.

Dlugokencky, E. J., Bruhwiler, L., White, J. W. C., Emmons, L. K., Novelli, P. C., Montzka, S. A., Masarie, K. A., Lang, P. M., Crotwell, A. M., Miller, J. B., and Gatti, L. V.: Observational constraints on recent increases in the atmospheric $\mathrm{CH}_{4}$ burden, Geophys. Res. Lett., 36, L18803, https://doi.org/10.1029/2009GL039780, 2009.

Dlugokencky, E. J., Nisbet, E. G., Fisher, R., and Lowry, D.: Global atmospheric methane: budget, changes and dangers, Philos. T. R. Soc. A, 369, 2058-2072, 2011.

Dlugokencky, E. J., Lang, P. M., Crotwell, A. M., Mund, J. W., Crotwell, M. J., and Thoning, K. W.: Atmospheric Methane Dry Air Mole Fractions from the NOAA ESRL Carbon Cycle Cooperative Global Air Sampling Network, 1983-2017, Version: 2018-08-01, available at: ftp://aftp.cmdl.noaa.gov/data/ trace_gases/ch4/flask/surface/, last access: August 2018.

Etheridge, D. M., Steele, L. P., Francy, R. J., and Langenfelds, R. L.: Atmospheric methane between 1000 A. D. and present: Evidence of anthropogenic emissions and climatic variability, J. Geophys. Res., 103, 15979-15993, 1998.

Etiope, G. and Milkov, A. V.: A new estimate of global methane flux from onshore and shallow submarine mud volcanoes to the atmosphere, Environ. Geol., 46, 997-1002, https://doi.org/10.1007/s00254-004-1085-1, 2004. 
Fiore, A. M., Jacob, D. J., Field, B. D., Streets, D. G., Fernandes, S. D., and Jang, C.: Linking ozone pollution and climate change: The case for controlling methane, Geophys. Res. Lett., 29, 1919, https://doi.org/10.1029/2002GL015601, 2002.

Fiore, A. M., Horowitz, L. W., Dlugokencky, E. J., and West, J. J.: Impact of meteorology and emissions on methane trends, 1990-2004, Geophys. Res. Lett., 33, L12809, https://doi.org/10.1029/2006GL026199, 2006.

Fung, I., John, J., Lerner, J., Matthews, E., Prather, M., Steele, L. P., and Fraser, P. J.: Three-dimensional model synthesis of the global methane cycle, J. Geophys. Res., 96, 13033-13065, 1991.

Ghosh, A., Patra, P. K., Ishijima, K., Umezawa, T., Ito, A., Etheridge, D. M., Sugawara, S., Kawamura, K., Miller, J. B., Dlugokencky, E. J., Krummel, P. B., Fraser, P. J., Steele, L. P., Langenfelds, R. L., Trudinger, C. M., White, J. W. C., Vaughn, B., Saeki, T., Aoki, S., and Nakazawa, T.: Variations in global methane sources and sinks during 1910-2010, Atmos. Chem. Phys., 15, 2595-2612, https://doi.org/10.5194/acp15-2595-2015, 2015.

Gidden, M. J., Riahi, K., Smith, S. J., Fujimori, S., Luderer, G., Kriegler, E., van Vuuren, D. P., van den Berg, M., Feng, L., Klein, D., Calvin, K., Doelman, J. C., Frank, S., Fricko, O., Harmsen, M., Hasegawa, T., Havlik, P., Hilaire, J., Hoesly, R., Horing, J., Popp, A., Stehfest, E., and Takahashi, K.: Global emissions pathways under different socioeconomic scenarios for use in CMIP6: a dataset of harmonized emissions trajectories through the end of the century, Geosci. Model Dev., 12, 14431475, https://doi.org/10.5194/gmd-12-1443-2019, 2019.

Gromov, S., Brenninkmeijer, C. A. M., and Jöckel, P.: A very limited role of tropospheric chlorine as a sink of the greenhouse gas methane, Atmos. Chem. Phys., 18, 9831-9843, https://doi.org/10.5194/acp-18-9831-2018, 2018.

Guenther, A., Karl, T., Harley, P., Wiedinmyer, C., Palmer, P. I., and Geron, C.: Estimates of global terrestrial isoprene emissions using MEGAN (Model of Emissions of Gases and Aerosols from Nature), Atmos. Chem. Phys., 6, 3181-3210, https://doi.org/10.5194/acp-6-3181-2006, 2006.

Hausmann, P., Sussmann, R., and Smale, D.: Contribution of oil and natural gas production to renewed increase in atmospheric methane (2007-2014): top-down estimate from ethane and methane column observations, Atmos. Chem. Phys., 16, 3227-3244, https://doi.org/10.5194/acp-16-3227-2016, 2016.

Hess, P. G., Flocke, S., Lamarque, J.-F., Barth, M. C., and Madronich, S.: Episodic modeling of the chemical structure of the troposphere as revealed during the spring MLOPEX intensive, J. Geophys. Res., 105, 26809-26839, 2000.

Hoesly, R. M., Smith, S. J., Feng, L., Klimont, Z., JanssensMaenhout, G., Pitkanen, T., Seibert, J. J., Vu, L., Andres, R. J., Bolt, R. M., Bond, T. C., Dawidowski, L., Kholod, N., Kurokawa, J.-I., Li, M., Liu, L., Lu, Z., Moura, M. C. P., O'Rourke, P. R., and Zhang, Q.: Historical (1750-2014) anthropogenic emissions of reactive gases and aerosols from the Community Emissions Data System (CEDS), Geosci. Model Dev., 11, 369-408, https://doi.org/10.5194/gmd-11-369-2018, 2018.

Holmes, C. D.: Methane Feedback on Atmospheric Chemistry: Methods, models, and mechanisms, J. Adv. Model. Earth Syst., 10, 1087-1099, https://doi.org/10.1002/2017MS001196, 2018.

Horowitz, L. W., Walters, S., Mauzerall, D. L., Emmons, L. K., Rasch, P. J., Granier, C., Tie, X., Lamarque, J.-F., Schultz, M.
G., Tyndall, G. S., Orlando, J. J., and Brasseur, G. P.: A global simulation of tropospheric ozone and related tracers: Description and evaluation of MOZART, version 2, J. Geophys. Res.-Atmos., 108, 4784, https://doi.org/10.1029/2002JD002853, 2003.

Horowitz, L. W., Naik, V., Paulot, F., Ginoux, P. A., Dunne, J. P., Mao, J., Schnell, J., Chen, X., He, J., Lin, M., Lin, P., Malyshev, S., Paynter, D., Shevliakova, E., and Zhao, M.: The GFDL Global Atmospheric Chemistry-Climate Model AM4.1: Model Description and Simulation Characteristics, J. Adv. Model. Earth Syst., submitted, 2020.

Hossaini, R., Chipperfield, M. P., Saiz-Lopez, A., Fernandez, R., Monks, S., Feng, W., Brauer, P., and von Glasow, R.: A global model of tropospheric chlorine chemistry: Organic versus inorganic sources and impact on methane oxidation, J. Geophys. Res.-Atmos., 121, 14271-14297, https://doi.org/10.1002/2016JD025756, 2016.

Houweling, S., Krol, M., Bergamaschi, P., Frankenberg, C., Dlugokencky, E. J., Morino, I., Notholt, J., Sherlock, V., Wunch, D., Beck, V., Gerbig, C., Chen, H., Kort, E. A., Röckmann, T., and Aben, I.: A multi-year methane inversion using SCIAMACHY, accounting for systematic errors using TCCON measurements, Atmos. Chem. Phys., 14, 3991-4012, https://doi.org/10.5194/acp-14-3991-2014, 2014.

Houweling, S., Bergamaschi, P., Chevallier, F., Heimann, M., Kaminski, T., Krol, M., Michalak, A. M., and Patra, P.: Global inverse modeling of $\mathrm{CH}_{4}$ sources and sinks: an overview of methods, Atmos. Chem. Phys., 17, 235-256, https://doi.org/10.5194/acp-17-235-2017, 2017.

Kai, F. M., Tyler, S. C., Randerson, J. T., and Blake, D. R.: Reduced methane growth rate explained by decreased Northern Hemisphere microbial sources, Nature, 476, 194-197, 2011.

Kaylnay, E., Kanamitsu, M., Kistler, R., Collins, W., Deaven, D., Gandin, L., Iredell, M., Saha, S., White, G., Woollen, J., Zhu, Y., Chelliah, M., Ebisuzaki, W., Higgins, W., Janowiak, J., Mo, K. C., Ropelewski, C., Wang, J., Leetmaa, A., Reynolds, R., Jenne, R., and Joseph, D.: The NCEP/NCAR 40-year reanalysis project, B. Am. Meteorol. Soc., 77, 437-471, https://doi.org/10.1175/15200477(1996)077<0437:TNYRP>2.0.CO;2, 1996.

Kirschke, S., Bousquet, P., Ciais, P., Saunois, M., Canadell, J. G., Dlugokencky, E. J., Bergamaschi, P., Bergmann, D., Blake, D. R., Bruhwiler, L., Cameron-Smith, P., Castaldi, S., Chevallier, F., Feng, L., Fraser, A., Heimann, M., Hodson, E. L., Houweling, S., Josse, B., Fraser, P. J., Krummel, P. B., Lamarque, J.F., Langenfelds, R. L., Le Quere, C., Naik, V., O’Doherty, S., Palmer, P. I., Pison, I., Plummer, D., Poulter, B., Prinn, R. G., Rigby, M., Ringeval, B., Santini, M., Schmidt, M., Shindell, D. T., Simpson, I. J., Spahni, R., Steele, L. P., Strode, S. A., Sudo, K., Szopa, S., van der Werf, G. R., Voulgarakis, A., van Weele, M., Weiss, R. F., Williams, J. E., and Zeng, G.: Three decades of global methane sources and sinks, Nat. Geosci., 6, 813-823, https://doi.org/10.1038/ngeo1955, 2013.

Knox, S. H., Matthes, J. H., Sturtevant, C., Oikawa, P. Y., Verfaillie, J., and Baldocchi, D.: Biophysical controls on interannual variability in ecosystem-scale $\mathrm{CO}_{2}$ and $\mathrm{CH}_{4}$ exchange in a California rice paddy, J. Geophys. Res.-Biogeo., 121, 978-1001, https://doi.org/10.1002/2015JG003247, 2016.

Lambert, G. and Schmidt, S.: Reevaluation of the oceanic flux of methane: uncertainties and long term variations, Chemosph. 
Global Change Sci., 26, 579-589, https://doi.org/10.1016/00456535(93)90443-9, 1993.

Levin, I., Veidt, C., Vaughn, B. H., Brailsford, G., Bromley, T., Lowe, R. H. D., Miller, J. B., Poß, C., and White, J. W. C.: No inter-hemispheric $\delta^{13} \mathrm{CH}_{4}$ trend observed, Nature, 486, E3-E4, https://doi.org/10.1038/nature11175, 2012.

Lin, M., Fiore, A. M., Horowitz, L. W., Cooper, O. R., Naik, V., Holloway, J., Johnson, B. J., Middlebrook, A. M., Oltmans, S. J., Pollack, I. B., Ryerson, T. B., Warner, J. X., Wiedinmyer, C., Wilson, J., and Wyman, B.: Transport of Asian ozone pollution into surface air over the western United States in spring, J. Geophys. Res.-Atmos., 117, D00V07, https://doi.org/10.1029/2011JD016961, 2012.

Maasakkers, J. D., Jacob, D. J., Sulprizio, M. P., Scarpelli, T. R., Nesser, H., Sheng, J.-X., Zhang, Y., Hersher, M., Bloom, A. A., Bowman, K. W., Worden, J. R., Janssens-Maenhout, G., and Parker, R. J.: Global distribution of methane emissions, emission trends, and $\mathrm{OH}$ concentrations and trends inferred from an inversion of GOSAT satellite data for 2010-2015, Atmos. Chem. Phys., 19, 7859-7881, https://doi.org/10.5194/acp-197859-2019, 2019.

Mao, J., Fan, S., Jacob, D. J., and Travis, K. R.: Radical loss in the atmosphere from $\mathrm{Cu}-\mathrm{Fe}$ redox coupling in aerosols, Atmos. Chem. Phys., 13, 509-519, https://doi.org/10.5194/acp-13-5092013, 2013a.

Mao, J., Horowitz, L. W., Naik, V., Fan, S., Liu, J., and Fiore, A. M.: Sensitivity of tropospheric oxidants to biomass burning emissions: implications for radiative forcing, Geophys. Res. Lett., 40, 1241-1246, https://doi.org/10.1002/grl.50210, 2013b.

Monteil, G., Houweling, S., Dlugockenky, E. J., Maenhout, G., Vaughn, B. H., White, J. W. C., and Rockmann, T.: Interpreting methane variations in the past two decades using measurements of $\mathrm{CH}_{4}$ mixing ratio and isotopic composition, Atmos. Chem. Phys., 11, 9141-9153, https://doi.org/10.5194/acp11-9141-2011, 2011.

Montzka, S. A., Krol, M., Dlugokencky, E., Hall, B., Jockel, P., and Lelieveld, J.: Small interannual variability of global atmospheric hydroxyl, Science, 331, 67-69, https://doi.org/10.1126/science.1197640, 2011.

Murray, L. T., Logan, J. A., and Jacob, D. J.: Interannual variability in tropical tropospheric ozone and $\mathrm{OH}$ : the role of lightning, J. Geophys. Res., 118, 1-13, https://doi.org/10.1002/jgrd.50857, 2013.

Myhre, G., Shindell, D., Bréon, F.-M., Collins, W. Fuglestvedt, J., Huang, J., Koch, D. Lamarque, J.-F., Lee, D., Mendoza, B., Nakajima, T., Robock, A., Stephens, G. Takemura, T., and Zhang, H.: Anthropogenic and natural radiative forcing, in: Climate Change 2013: The Physical Science Basis, Fifth Assessment Report of the Intergovernmental Panel on Climate Change, edited by: Stocker, T. F., Qin, D., Plattner, G.-K., Tignor, M., Allen, S. K., Boschung, J., Nauels, A., Xia, Y., Bex, V., and Midgley, P. M., Cambridge University Press, Cambridge, UK, New York, NY, USA, 659-740, 2013.

Naik, V., Horowitz, L. W., Fiore, A. M., Ginoux, P., Mao, J., Aghedo, A. M., and Levy, H.: Impact of preindustrial to presentday changes in short-lived pollutant emissions on atmospheric composition and climate forcing, J. Geophys. Res.-Atmos., 118, 8086-8110, https://doi.org/10.1002/jgrd.50608, 2013a.
Naik, V., Voulgarakis, A., Fiore, A. M., Horowitz, L. W., Lamarque, J.-F., Lin, M., Prather, M. J., Young, P. J., Bergmann, D., Cameron-Smith, P. J., Cionni, I., Collins, W. J., Dalsøren, S. B., Doherty, R., Eyring, V., Faluvegi, G., Folberth, G. A., Josse, B., Lee, Y. H., MacKenzie, I. A., Nagashima, T., van Noije, T. P. C., Plummer, D. A., Righi, M., Rumbold, S. T., Skeie, R., Shindell, D. T., Stevenson, D. S., Strode, S., Sudo, K., Szopa, S., and Zeng, G.: Preindustrial to present-day changes in tropospheric hydroxyl radical and methane lifetime from the Atmospheric Chemistry and Climate Model Intercomparison Project (ACCMIP), Atmos. Chem. Phys., 13, 5277-5298, https://doi.org/10.5194/acp13-5277-2013, 2013b.

Naus, S., Montzka, S. A., Pandey, S., Basu, S., Dlugokencky, E. J., and Krol, M.: Constraints and biases in a tropospheric two-box model of $\mathrm{OH}$, Atmos. Chem. Phys., 19, 407-424, https://doi.org/10.5194/acp-19-407-2019, 2019.

Nisbet, E. G., Dlugokencky, E. J., and Bousquet, P.: Methane on the Rise - Again, Science, 343, 493-495, https://doi.org/10.1126/science.1247828, 2014.

Nisbet, E. G., Dlugokencky, E. J., Manning, M. R., Lowry, D., Fisher, R. E., France, J. L., Michel, S. E., Miller, J. B., White, J. W. C., Vaughn, B., Bousquet, P., Pyle, J. A., Warwick, N. J., Cain, M., Brownlow, R., Zazzeri, G., Lanoisellé, M., Manning, A. C., Gloor, E., Worthy, D. E. J., Brunke, E.-G., Labuschagne, C., Wolff, E. W., and Ganesan, A. L.: Rising atmospheric methane: 2007-2014 growth and isotopic shift, Global Biogeochem. Cy., 30, 1356-1370, https://doi.org/10.1002/2016GB005406, 2016.

Nisbet, E. G., Manning, M. R., Dlugokencky, E. J., Fisher, R. E., Lowry, D., Michel, S. E., Myhre, C. L., Platt, S. M., Allen, G., Bousquet, P., Brownlow, R., Cain, M., France, J. L., Hermansen, O., Hossaini, R., Jones, A. E., Levin, I., Manning, A. C., Myhre, G., Pyle, J. A., Vaughn, B., Warwick, N. J., and White, J. W. C.: Very strong atmospheric methane growth in the four years 2014 2017: Implications for the Paris Agreement, Global Biogeochem. Cy., 33, 318-342, https://doi.org/10.1029/2018GB006009, 2019.

Patra, P. K., Houweling, S., Krol, M., Bousquet, P., Belikov, D., Bergmann, D., Bian, H., Cameron-Smith, P., Chipperfield, M. P., Corbin, K., Fortems-Cheiney, A., Fraser, A., Gloor, E., Hess, P., Ito, A., Kawa, S. R., Law, R. M., Loh, Z., Maksyutov, S., Meng, L., Palmer, P. I., Prinn, R. G., Rigby, M., Saito, R., and Wilson, C.: TransCom model simulations of $\mathrm{CH}_{4}$ and related species: linking transport, surface flux and chemical loss with $\mathrm{CH}_{4}$ variability in the troposphere and lower stratosphere, Atmos. Chem. Phys., 11, 12813-12837, https://doi.org/10.5194/acp-11-128132011, 2011.

Patra, P. K., Saeki, T., Dlugokencky, E. J., Ishijima, K., Umezawa, T., Ito, A., Aoki, S., Morimoto, S., Kort, E. A., Crotwell, A., Ravi Kumar, K., and Nakazawa, T.: Regional Methane Emission Estimation Based on Observed Atmospheric Concentrations (2002-2012), J. Met. Soc. Jap., 94, 91-112, https://doi.org/10.2151/jmsj.2016-006, 2016.

Paulot, F., Ginoux, P., Cooke, W. F., Donner, L. J., Fan, S., Lin, M.-Y., Mao, J., Naik, V., and Horowitz, L. W.: Sensitivity of nitrate aerosols to ammonia emissions and to nitrate chemistry: implications for present and future nitrate optical depth, Atmos. Chem. Phys., 16, 1459-1477, https://doi.org/10.5194/acp16-1459-2016, 2016.

Prather, M. J., Holmes, C. D., and Hsu, J.: Reactive greenhouse gas scenarios: Systematic exploration of uncertainties and the 
role of atmospheric chemistry, Geophys. Res. Lett., 39, L09803, https://doi.org/10.1029/2012gl051440, 2012.

Rice, A. L., Butenhoff, C. L., Teama, D. G., Röger, F. H., Khalil, M. A. K., and Rasmussen, R. A.: Atmospheric methane isotopic record favors fossil sources flat in 1980s and 1990s with recent increase, P. Natl. Acad. Sci. USA, 113, 10791-10796, https://doi.org/10.1073/pnas.1522923113, 2016.

Rigby, M., Prinn, R. G., Fraser, P. J., Simmonds, P. G., Langenfelds, R. L., Huang, J., Cunnold, D. M., Steele, L. P., Krummel, P. B., Weiss, R. F., O’Doherty, S., Salameh, P. K., Wang, H. J., Harth, C. M., Mühle, J., and Porter, L. W.: Renewed growth of atmospheric methane, Geophys. Res. Lett., 35, L22805, https://doi.org/10.1029/2008GL036037, 2008.

Rigby, M., Manning, A. J., and Prinn, R. G.: The value of high frequency, high-precision methane isotopologue measurements for source and sink estimation, J. Geophys. Res.-Atmos., 117, D12312, https://doi.org/10.1029/2011jd017384, 2012.

Rigby, M., Montzka, S. A., Prinn, R. G., White, J. W. C., Young, D., O’Doherty, S., Lunt, M. F., Ganesan, A. L., Manning, A. J., Simmonds, P. G., Salameh, P. K., Harth, C. M., Mühle, J., Weiss, R. F., Fraser, P. J., Steele, L. P., Krummel, P. B., McCulloch, A., and Park, S.: Role of atmospheric oxidation in recent methane growth, P. Natl. Acad. Sci. USA, 114, 5373-5377, https://doi.org/10.1073/pnas.1616426114, 2017.

Saeki, T. and Patra, P. K.: Implications of overestimated anthropogenic $\mathrm{CO}_{2}$ emissions on East Asian and global land $\mathrm{CO}_{2}$ flux inversion, Geosci. Lett., 4, 9, https://doi.org/10.1186/s40562017-0074-7, 2017.

Saunois, M., Bousquet, P., Poulter, B., Peregon, A., Ciais, P., Canadell, J. G., Dlugokencky, E. J., Etiope, G., Bastviken, D., Houweling, S., Janssens-Maenhout, G., Tubiello, F. N., Castaldi, S., Jackson, R. B., Alexe, M., Arora, V. K., Beerling, D. J., Bergamaschi, P., Blake, D. R., Brailsford, G., Brovkin, V., Bruhwiler, L., Crevoisier, C., Crill, P., Covey, K., Curry, C., Frankenberg, C., Gedney, N., Höglund-Isaksson, L., Ishizawa, M., Ito, A., Joos, F., Kim, H.-S., Kleinen, T., Krummel, P., Lamarque, J.-F., Langenfelds, R., Locatelli, R., Machida, T., Maksyutov, S., McDonald, K. C., Marshall, J., Melton, J. R., Morino, I., Naik, V., O’Doherty, S., Parmentier, F.-J. W., Patra, P. K., Peng, C., Peng, S., Peters, G. P., Pison, I., Prigent, C., Prinn, R., Ramonet, M., Riley, W. J., Saito, M., Santini, M., Schroeder, R., Simpson, I. J., Spahni, R., Steele, P., Takizawa, A., Thornton, B. F., Tian, H., Tohjima, Y., Viovy, N., Voulgarakis, A., van Weele, M., van der Werf, G. R., Weiss, R., Wiedinmyer, C., Wilton, D. J., Wiltshire, A., Worthy, D., Wunch, D., Xu, X., Yoshida, Y., Zhang, B., Zhang, Z., and Zhu, Q.: The global methane budget 2000-2012, Earth Syst. Sci. Data, 8, 697-751, https://doi.org/10.5194/essd-8-697-2016, 2016.

Saunois, M., Bousquet, P., Poulter, B., Peregon, A., Ciais, P., Canadell, J. G., Dlugokencky, E. J., Etiope, G., Bastviken, D., Houweling, S., Janssens-Maenhout, G., Tubiello, F. N., Castaldi, S., Jackson, R. B., Alexe, M., Arora, V. K., Beerling, D. J., Bergamaschi, P., Blake, D. R., Brailsford, G., Bruhwiler, L., Crevoisier, C., Crill, P., Covey, K., Frankenberg, C., Gedney, N., HöglundIsaksson, L., Ishizawa, M., Ito, A., Joos, F., Kim, H.-S., Kleinen, T., Krummel, P., Lamarque, J.-F., Langenfelds, R., Locatelli, R., Machida, T., Maksyutov, S., Melton, J. R., Morino, I., Naik, V., O'Doherty, S., Parmentier, F.-J. W., Patra, P. K., Peng, C., Peng, S., Peters, G. P., Pison, I., Prinn, R., Ramonet, M., Ri- ley, W. J., Saito, M., Santini, M., Schroeder, R., Simpson, I. J., Spahni, R., Takizawa, A., Thornton, B. F., Tian, H., Tohjima, Y., Viovy, N., Voulgarakis, A., Weiss, R., Wilton, D. J., Wiltshire, A., Worthy, D., Wunch, D., Xu, X., Yoshida, Y., Zhang, B., Zhang, Z., and Zhu, Q.: Variability and quasi-decadal changes in the methane budget over the period 2000-2012, Atmos. Chem. Phys., 17, 11135-11161, https://doi.org/10.5194/acp-17-111352017, 2017.

Saunois, M., Stavert, A. R., Poulter, B., Bousquet, P., Canadell, J. G., Jackson, R. B., Raymond, P. A., Dlugokencky, E. J., Houweling, S., Patra, P. K., Ciais, P., Arora, V. K., Bastviken, D., Bergamaschi, P., Blake, D. R., Brailsford, G., Bruhwiler, L., Carlson, K. M., Carrol, M., Castaldi, S., Chandra, N., Crevoisier, C., Crill, P. M., Covey, K., Curry, C. L., Etiope, G., Frankenberg, C., Gedney, N., Hegglin, M. I., Höglund-Isaksson, L., Hugelius, G., Ishizawa, M., Ito, A., Janssens-Maenhout, G., Jensen, K. M., Joos, F., Kleinen, T., Krummel, P. B., Langenfelds, R. L., Laruelle, G. G., Liu, L., Machida, T., Maksyutov, S., McDonald, K. C., McNorton, J., Miller, P. A., Melton, J. R., Morino, I., Müller, J., Murgia-Flores, F., Naik, V., Niwa, Y., Noce, S., O’Doherty, S., Parker, R. J., Peng, C., Peng, S., Peters, G. P., Prigent, C., Prinn, R., Ramonet, M., Regnier, P., Riley, W. J., Rosentreter, J. A., Segers, A., Simpson, I. J., Shi, H., Smith, S. J., Steele, L. P., Thornton, B. F., Tian, H., Tohjima, Y., Tubiello, F. N., Tsuruta, A., Viovy, N., Voulgarakis, A., Weber, T. S., van Weele, M., van der Werf, G. R., Weiss, R. F., Worthy, D., Wunch, D., Yin, Y., Yoshida, Y., Zhang, W., Zhang, Z., Zhao, Y., Zheng, B., Zhu, Q., Zhu, Q., and Zhuang, Q.: The Global Methane Budget 2000-2017, Earth Syst. Sci. Data Discuss., https://doi.org/10.5194/essd-2019-128, in review, 2020.

Schaefer, H., Fletcher, S. E. M., Veidt, C., Lassey, K. R., Brailsford, G. W., Bromley, T. M., Dlugokencky, E. J., Michel, S. E., Miller, J. B., Levin, I., Lowe, D. C., Martin, R. J., Vaughn, B. H., and White, J. W. C.: A 21st century shift from fossil-fuel to biogenic methane emissions indicated by ${ }^{13} \mathrm{CH}_{4}$, Science, 352, 80-84, https://doi.org/10.1126/science.aad2705, 2016.

Schnell, J. L., Naik, V., Horowitz, L. W., Paulot, F., Mao, J., Ginoux, P., Zhao, M., and Ram, K.: Exploring the relationship between surface $\mathrm{PM}_{2.5}$ and meteorology in Northern India, Atmos. Chem. Phys., 18, 10157-10175, https://doi.org/10.5194/acp-18-101572018, 2018.

Schumann, U. and Huntrieser, H.: The global lightning-induced nitrogen oxides source, Atmos. Chem. Phys., 7, 3823-3907, https://doi.org/10.5194/acp-7-3823-2007, 2007.

Schwietzke, S, Sherwood, O. A., Bruhwiler, L. M. P., Miller, J. B., Etiope, G., Dlugokencky, E. J., Michel, S. E., Arline, V. A., Vaughn, B. H., White, J. W. C., and Tans, P. P.: Upward revision of global fossil fuel methane emissions based on isotope database, Nature, 538, 88-91, https://doi.org/10.1038/nature19797, 2016.

Shindell, D., Kuylenstierna, J. C. I., Vignati, E., van Dingenen, R., Amann, M., Klimont, Z., Anenberg, S. C., Muller, N., JanssensMaenhout, G., Raes, F., Schwartz, J., Faluvegi, G., Pozzoli, L., Kupiainen, K., Höglund-Isaksson, L., Emberson, L., Streets, D., Ramanathan, V., Hicks, K., Oanh, N. T. K., Milly, G., Williams, M., Demkine, V., and Fowler, D.: Simultaneously mitigating near-term climate change and improving human health and food security, Science, 335, 183-189, 2012. 
Simpson, I. J., Sulbaek Andersen, M. P., Meinardi, S., Bruhwiler, L., Blake, N. J., Helmig, D., Rowland, F. S., and Blake, D. R.: Long-term decline of global atmospheric ethane concentrations and implications for methane, Nature, 488, 490-494, 2012.

Tans, P. P., Conway, T. J., and Nakazawa, T.: Latitudinal distribution of the sources and sinks of atmospheric carbon dioxide derived from surface observations and an atmospheric transport model, J. Geophys. Res., 94, 5151-5172, https://doi.org/10.1029/JD094iD04p05151, 1989.

Taylor, K. E., Williamson, D., and Zwiers, F.: The sea surface temperature and sea-ice concentration boundary conditions of AMIP II simulations, PCMDI Rep. 60, 20 pp., Program for Climate Model Diagnosis and Intercomparison, Lawrence Livermore National Laboratory, Livermore, CA, 2000.

Thompson, R. L., Stohl, A., Zhou, L. X., Dlugokencky, E., Fukuyama, Y., Tohjima, Y., Kim, S. Y., Lee, H., Nisbet, E. G., Fisher, R. E., Lowry, D., Weiss, R. F., Prinn, R. G., O'Doherty, S., Young, D., and White, J. W. C.: Methane emissions in East Asia for 2000-2011 estimated using an atmospheric Bayesian inversion, J. Geophys. Res.-Atmos., 120, 4352-4369, https://doi.org/10.1002/2014JD022394, 2015.

Thoning, K. W.: Curve Fitting Methods Applied to Time Series in NOAA/ESRL/GMD, available at: https://www.esrl.noaa.gov/ gmd/ccgg/mbl/crvfit/crvfit.html, last access: August 2019.

Thoning, K. W., Tans, P. P., and Komhyr, W. D.: Atmospheric carbon dioxide at Mauna Loa Observatory, 2. Analysis of the NOAA/GMCC data, 1974-1985, J. Geophys. Res., 94, 8549$8565,1989$.

Tsuruta, A., Aalto, T., Backman, L., Hakkarainen, J., van der LaanLuijkx, I. T., Krol, M. C., Spahni, R., Houweling, S., Laine, M., Dlugokencky, E., Gomez-Pelaez, A. J., van der Schoot, M., Langenfelds, R., Ellul, R., Arduini, J., Apadula, F., Gerbig, C., Feist, D. G., Kivi, R., Yoshida, Y., and Peters, W.: Global methane emission estimates for 2000-2012 from CarbonTracker Europe-CH4 v1.0, Geosci. Model Dev., 10, 1261-1289, https://doi.org/10.5194/gmd-10-1261-2017, 2017.

Turner, A. J., Frankenberg, C., Wennberg, P. O., and Jacob, D. J.: Ambiguity in the causes for decadal trends in atmospheric methane and hydroxyl, P. Natl. Acad. Sci. USA, 114, 5367-5372, https://doi.org/10.1073/pnas.1616020114, 2017.

van Marle, M. J. E., Kloster, S., Magi, B. I., Marlon, J. R., Daniau, A.-L., Field, R. D., Arneth, A., Forrest, M., Hantson, S., Kehrwald, N. M., Knorr, W., Lasslop, G., Li, F., Mangeon, S., Yue, C., Kaiser, J. W., and van der Werf, G. R.: Historic global biomass burning emissions for CMIP6 (BB4CMIP) based on merging satellite observations with proxies and fire models (1750-2015), Geosci. Model Dev., 10, 3329-3357, https://doi.org/10.5194/gmd-10-3329-2017, 2017.

Voulgarakis, A., Naik, V., Lamarque, J.-F., Shindell, D. T., Young, P. J., Prather, M. J., Wild, O., Field, R. D., Bergmann, D., CameronSmith, P., Cionni, I., Collins, W. J., Dalsøren, S. B., Doherty, R. M., Eyring, V., Faluvegi, G., Folberth, G. A., Horowitz, L. W., Josse, B., MacKenzie, I. A., Nagashima, T., Plummer, D. A., Righi, M., Rumbold, S. T., Stevenson, D. S., Strode, S. A., Sudo, K., Szopa, S., and Zeng, G.: Analysis of present day and future $\mathrm{OH}$ and methane lifetime in the ACCMIP simulations, Atmos. Chem. Phys., 13, 2563-2587, https://doi.org/10.5194/acp13-2563-2013, 2013.
Wang, X., Jacob, D. J., Eastham, S. D., Sulprizio, M. P., Zhu, L., Chen, Q., Alexander, B., Sherwen, T., Evans, M. J., Lee, B. H., Haskins, J. D., Lopez-Hilfiker, F. D., Thornton, J. A., Huey, G. L., and Liao, H.: The role of chlorine in global tropospheric chemistry, Atmos. Chem. Phys., 19, 3981-4003, https://doi.org/10.5194/acp-19-3981-2019, 2019.

Wesely, M. L.: Parameterization of surface resistances to gaseous dry deposition in regional-scale numerical models, Atmos. Environ., 23, 1293-1304, 1989.

Wofsy, S. C., Team, H. S., Team, C. M., and Team, S.: HIAPER Pole-to-Pole Observations (HIPPO): fine-grained, globalscale measurements of climatically important atmospheric gases and aerosols, Philos. T. R. Soc. A, 369, 2073-2086, https://doi.org/10.1098/rsta.2010.0313, 2011.

Wofsy, S. C., Daube, B. C., Jimenez, R., Kort, E., Pittman, J. V., Park, S., Commane, R., Xiang, B., Santoni, G., Jacob, D., Fisher, J., Pickett-Heaps, C., Wang, H., Wecht, K., Wang, Q.-Q., Stephens, B. B., Shertz, S., Watt, A. S., Romashkin, P., Campos, T., HaGggerty, J., Cooper, W. A., Rogers, D., Beaton, S., Hendershot, R., Elkins, J. W., Fahey, D. W., Gao, R. S., Moore, F., Montzka, S. A., Schwarz, J. P., Perring, A. E., Hurst, D., Miller, B. R., Sweeney, C., Oltmans, S., Nance, D., Hintsa, E., Dutton, G., Watts, L. A., Spackman, J. R., Rosenlof, K. H., Ray, E. A., Hall, B., Zondlo, M. A., Diao, M., Keeling, R., Bent, J., Atlas, E. L., Lueb, R., Mahoney, M. J.: HIPPO Merged 10-second Meteorology, Atmospheric Chemistry, Aerosol Data (R_20121129). Carbon Dioxide Information Analysis Center, Oak Ridge National Laboratory, Oak Ridge, Tennessee, USA, https://doi.org/10.3334/CDIAC/hippo_010 (Release 20121129) (last access: July 2018), 2012.

Worden, J. R., Bloom, A. A., Pandey, S., Jiang, Z., Worden, H. M., Walker, T. W., Houweling, S., and Röckmann, T.: Reduced biomass burning emissions reconcile conflicting estimates of the post-2006 atmospheric methane budget, Nat. Commun., 8, 2227, https://doi.org/10.1038/s41467-017-02246-0, 2017.

Zhao, M., Golaz, J.-C., Held, I. M., Guo, H., Balaji, V., Renson, R., Chen, J.-H., Chen, X., Donner, L. J., Dunne, J. P., Dunne, K., Durachta, J., Fan, S.-M., Freidenreich, S. M., Garner, S. T., Ginoux, P., Harris, L. M., Horowitz, L. W., Krasting, J. P., Langenhorst, A. R., Liang, Z., Lin, P., Lin, S.-J., Malyshev, S. L., Mason, E., Milly, P. C. D., Ming, Y., Naik, V., Paulot, F., Paynter, D., Phillipps, P., Radhakrishnan, A., Ramaswamy, V., Robinson, T., Schwarzkopf, D., Seman, C. J., Shevliakova, E., Shen, Z., Shin, H., Silvers, L. G., Wilson, J. R., Winton, M., Wittenberg, A. T., Wyman, B., and Xian, B.: The GFDL global atmosphere and land model AM4.0/LM4.0: 1. Simulation characteristics with prescribed SSTs, J. Adv. Model. Earth Syst., 10, 691734, https://doi.org/10.1002/2017MS001208, 2018a.

Zhao, M., Golaz, J.-C., Held, I. M., Guo, H., Balaji, V., Renson, R., Chen, J.-H., Chen, X., Donner, L. J., Dunne, J. P., Dunne, K., Durachta, J., Fan, S.-M., Freidenreich, S. M., Garner, S. T., Ginoux, P., Harris, L. M., Horowitz, L. W., Krasting, J. P., Langenhorst, A. R., Liang, Z., Lin, P., Lin, S.-J., Malyshev, S. L., Mason, E., Milly, P. C. D., Ming, Y., Naik, V., Paulot, F., Paynter, D., Phillipps, P., Radhakrishnan, A., Ramaswamy, V., Robinson, T., Schwarzkopf, D., Seman, C. J., Shevliakova, E., Shen, Z., Shin, H., Silvers, L. G., Wilson, J. R., Winton, M., Wittenberg, A. T., Wyman, B., and Xian, B.: The GFDL global atmosphere and land model AM4.0/LM4.0: 2. Model description, sensitiv- 
ity studies, and tuning strategies, J. Adv. Model. Earth Syst., 10, 735-769, https://doi.org/10.1002/2017MS001209, 2018b.

Zhao, Y., Saunois, M., Bousquet, P., Lin, X., Berchet, A., Hegglin, M. I., Canadell, J. G., Jackson, R. B., Hauglustaine, D. A., Szopa, S., Stavert, A. R., Abraham, N. L., Archibald, A. T., Bekki, S., Deushi, M., Jöckel, P., Josse, B., Kinnison, D., Kirner, O., Marécal, V., O'Connor, F. M., Plummer, D. A., Revell, L. E., Rozanov, E., Stenke, A., Strode, S., Tilmes, S., Dlugokencky, E. J., and Zheng, B.: Inter-model comparison of global hydroxyl radical $(\mathrm{OH})$ distributions and their impact on atmospheric methane over the 2000-2016 period, Atmos. Chem. Phys., 19, 13701-13723, https://doi.org/10.5194/acp-19-13701-2019, 2019. 